\title{
Convex and Discrete Geometrical Problems on the Sphere \\ Ph.D. thesis
}

\section{Tamás Zarnócz}

\author{
Supervisor:
}

Ferenc Fodor, Ph.D.

Doctoral School of Mathematics

and Computer Science

University of Szeged, Bolyai Institute

Szeged

2019 


\section{Contents}

\begin{tabular}{|l|l}
\hline Acknowledgements & 4
\end{tabular}

\begin{tabular}{lll}
\hline 1 & Foreword & 5
\end{tabular}

\begin{tabular}{|lll}
2 & On the angle sum of lines & 8
\end{tabular}

2.1 Introduction . . . . . . . . . . . . . . . . . . . . 8

2.2 The planar case . . . . . . . . . . . . . . . . . . . . 10

2.3 Proof of Theorem $2.1 \ldots \ldots \ldots \ldots$

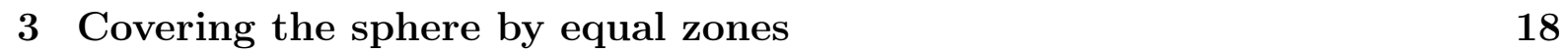

3.1 Introduction . . . . . . . . . . . . . . . . . . . . . . 18

3.2 Intersection of two zones . . . . . . . . . . . . . . . . . 20

3.3 A lower bound for the minimal width . . . . . . . . . . . . . . . . . . 24

4 On the multiplicity of arrangements of congruent zones on the sphere 29

4.1 Introduction . . . . . . . . . . . . . . . . . . . . . . . . . . . . . . . . . . 29

4.2 Proofs $\ldots \ldots \ldots \ldots \ldots$

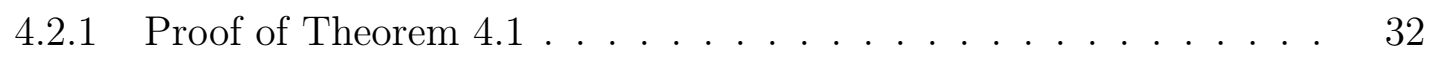

4.2 .2 Proof of Theorem $4.2 \ldots \ldots \ldots \ldots$

4.2 .3 Proof of Theorem $\mid 4.3 \ldots \ldots \ldots$. . . . . . . . . . . . . . . . 38

$4.2 .4 \quad$ Proof of Corollary $1 \ldots \ldots \ldots$

5 On the volume bound in the Dvoretzky-Rogers lemma 41

5.1 Introduction . . . . . . . . . . . . . . . . . 41

5.2 Proof of Lemma $5.2 \ldots \ldots \ldots \ldots$

5.3 Proofs of Theorem 5.5 and Proposition $5.6 \ldots \ldots \ldots$. . . . . . . 48

5.3 .1 Proof of Theorem 5.5 (ii) $\ldots \ldots \ldots \ldots$. . . . . . . . . 49

5.3 .2 Proof of Theorem 5.5 (ii) and (iii) . . . . . . . . . . . . 49

5.3 .3 Proof of Proposition 5.6 . . . . . . . . . . . . . . . . . . . . . . . . 49 
5.4 Proof of Theorem $5.7 \ldots \ldots \ldots \ldots$

$\begin{array}{lll}6 & \text { Summary } & 51\end{array}$

6.1 On the angle sum of lines . . . . . . . . . . . . . . . . 51

6.2 Covering the sphere by equal zones . . . . . . . . . . . . . 53

6.3 On the multiplicity of arrangements of congruent zones on the sphere . . 54

6.4 On the volume bound in the Dvoretzky-Rogers lemma . . . . . . . . . . 54

7. Összefoglaló $\quad 57$

7.1. Egyenesek szögösszegei . . . . . . . . . . . . . . . . . . . . . 57

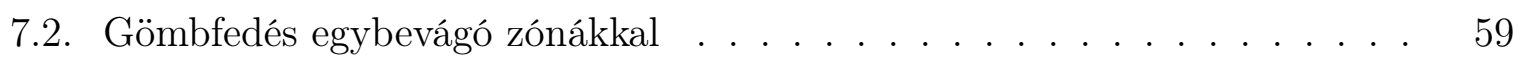

7.3. Egybevágó zónákból álló elrendezések multiplicitása . . . . . . . . . . . . 60

7.4. A Dvoretzky-Rogers lemmában szereplő térfogat-korlát . . . . . . . . . . 60

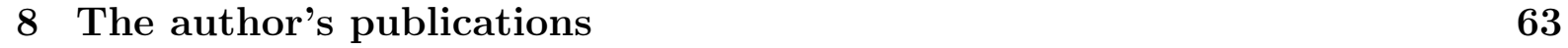




\section{Acknowledgements}

First of all, I would like to express my sincere gratitude to my advisor Professor Ferenc Fodor for his continuous support during my doctoral studies and my university years, for his patience, motivation, and immense knowledge. His guidance was invaluable for my research and the writing of this thesis.

I also thank my co-authors András Bezdek, Ferenc Fodor, Viktor Vígh, and Márton Naszódi for the joint research. I learnt a great deal from our discussions.

Last, but not least, I am also deeply grateful to my family and friends for their support through these long years. 


\section{Chapter 1}

\section{Foreword}

This doctoral thesis contains the results of the following four papers FVZ16a, FVZ16b, BFVZ17, FNZ18], each written with co-authors. The problems we discuss all come from convex and discrete geometry. The common theme, beside that all are related to the sphere, is the analytic approach. Discrete and convex geometry have very strong traditions in Hungary. The work of L. Fejes Tóth was fundamental in the development of these fields. It comes as no surprise that several of our problems have their origins in his papers.

Since the problems in this dissertation all have their individual histories, and the notation is always fitted to the particular setting, we rather give separate introductions to each chapter. Here, we only introduce the topics briefly, mentioning the main results and a short overview of their history.

Chapter 2 is based on the paper FVZ16b and is about maximizing the sum of pairwise angles formed by lines each incident with the origin (or any other common point). The problem dates back to 1959 when L. Fejes Tóth asked this question in the threedimensional Euclidean space. Solving it in the plane is rather straightforward, however, to the best of our knowledge the problem remains unsolved for three and higher dimensions (it is quite natural to extend the question to $d>3$ dimensions). L. Fejes Tóth himself conjectured that in the optimal configuration the lines together form the axes of a Cartesian coordinate system, and the number of lines on any two axes differ by at most one. He proved this conjecture for at most 6 lines, and he also gave an upper bound for the sum of angles for an arbitrary number of lines. Our main result of Chapter 2 is Theorem 2.1 in which we give an upper bound for the sum of the angles of $n$ lines in 3-dimensional space, thus improving the general bound of L. Fejes Tóth for large $n$. We note that after our paper had been published, Bilyk and Matzke [BM19] further improved 
the upper bound using a different method.

Chapter 3 contains the results of the paper [FVZ16a|. The problem discussed there also originates from L. Fejes Tóth [FT73]. He defined the so-called zones on the 3dimensional unit sphere, which are belt-like domains around a great circle, just like the surface of the Earth between the Tropics of Cancer and Capricorn. The precise definition is the following: a zone is the intersection of the sphere with the closed domain between two parallel planes, one of which is the reflection of the other with respect to the centre of the sphere. The problem is finding the minimal width such that a given number of zones of that common width can cover the whole sphere. This question is related to the famous plank problem of Tarski [Tar32]. According to the original conjecture of L. Fejes Tóth, this minimum width is $\pi$ divided by the number of zones. This is guaranteed to be sufficient, since one can arrange the zones in an orange-like pattern: all of the central great circles of the zones pass through, say the North and South Poles and they are distributed evenly, so they cover the Equator. The central great circle of a zone is the great circle parallel to its bounding planes. It was not known until recently that at least this width is also necessary. The main result of Chapter 3 is Theorem 3.6 , in which we give a non-trivial lower bound for the common width of the zones necessary to cover the sphere. We note that after our work had appeared, Jiang and Polyanskii [JP17] proved the original conjecture of L. Fejes Tóth.

Chapter 4, which is based on the paper [BFVZ17], has its roots in the same article of L. Fejes Tóth FT73 as Chapter 3. It deals with the problem of arranging congruent zones in a way that no point is covered by too many of them, that is, we try to minimize the maximum multiplicity of points in an arrangement of zones. We also consider the same question for coverings instead of general arrangements, that is, in order to cover the sphere with congruent zones how 'thick' the zones need to be placed. It is worth noting that in the optimal (orange-like) covering minimizing the width this multiplicity is maximal since all zones contain a neighbourhood of a pair of antipodal points. We seek to minimize this multiplicity as a function of the common width of the zones. Our main results in this Chapter 4 are Theorems 4.2 and 4.3 about general arrangements and coverings with zones, respectively.

In Chapter 5 of this thesis, we present the contents of the paper [FNZ18]. In this chapter we discuss the expectation of the square of the volume of random parallelotopes in isotropic measures, for the definition see (5.1) and (5.2). Pivovarov [Piv10] determined this expectation under the condition that the random vectors are linearly independent with probability 1 . One of our main results is Lemma 5.2 in which we extend the state- 
ment of Pivovarov for a larger class of probability measures. Subsequently, we apply Lemma 5.2 to so-called John decompositions of the identity, which naturally arise in connection with convex bodies. We know from the famous theorem of John Joh48 and Ball Bal92 that the unit ball is the unique maximum volume ellipsoid in a convex body if and only if there is a finite set of vectors, together with some suitable positive weights, among the contact points of the ball and the body that form an isotropic set of vectors, see (5.4), and that are centred, see (5.5). The lemma of Dvoretzky and Rogers, cf. Lemma 5.4. says that if we have a finite set of isotropic vectors on the unit sphere, then there is a subset of those vectors such that the parallelotope they span has relatively large volume. Pelczyński and Szarek PS91 improved the volume bound of Dvoretzky and Rogers. Using Lemma 5.2 and the fact that each finite set of isotropic vectors contains a subset of limited size which is also isotropic (with different weights), we give a probabilistic proof of the improved bound of Pelczyński and Szarek, and provide a probabilistic interpretation of the volume bound in the Dvoretzky-Rogers lemma. We also show that for isotropic vector sets of small cardinality the improvement is better, and in some cases even sharp. Our result regarding this is stated in Theorem 5.5. We finish this chapter by giving a lower bound on the probability that the volume of a random parallelotope from an isotropic set of vectors is at least as large as the bound of Pelczyński and Szarek, see Proposition 5.6 . 


\section{Chapter 2}

\section{On the angle sum of lines}

\section{$2.1 \quad$ Introduction}

This chapter is based on the paper [FVZ16a] written jointly with F. Fodor and V. Vígh. We start with a general overview and history of the problem, and also mention some recent developments on this topic that happened after the publication of the article. The original question we study in this part of the dissertation was raised by L. Fejes Tóth, as were many of the most important questions of discrete geometry of the 20th century. This particular question belongs to the family of problems that concern arrangements of points on the sphere in which the aim is to find configurations of a given number of points that maximize or minimize a certain quantity that depends on their mutual positions. Such quantities include, for example, the sum of Euclidean distances (or their powers) between the points, or the sum of spherical spherical distances. These problems are also connected to sphere packings; we will discuss some related questions in Chapter 3.

Consider $n$ lines in the $d$-dimensional Euclidean space $\mathbb{R}^{d}$ which all pass through the origin $o$. We note that the origin does not really play an important role here, we just essentially assume that the lines are concurrent. What is the maximum $S(n, d)$ of the sum of the pairwise (non-obtuse) angles formed by the lines? This question was originally raised by L. Fejes Tóth in 1959 in $[$ FT59 for $d=3$. It is very natural to ask the same question in higher dimensions as well. For general $d$, the problem is formulated, for example, in Pet14. One of the difficulties in this question is that the non-obtuse angle between two undirected lines behaves differently from the angle of two vectors or directed lines.

The conjectured maximum of the angle sum is attained by the following configuration: Let $n=k \cdot d+m(0 \leq m<d)$, and denote by $x_{1}, \ldots, x_{d}$ the axes of a Cartesian coordinate 
system in $\mathbb{R}^{d}$. Take $k+1$ copies of each one of the axes $x_{1}, \ldots, x_{m}$, and take $k$ copies of each one of the axes $x_{m+1}, \ldots, x_{d}$. The sum of the pairwise angles in this configuration is

$$
\left[\frac{d(d-1) k^{2}}{2}+m k(d-1)+\frac{m(m-1)}{2}\right] \frac{\pi}{2} .
$$

L. Fejes Tóth stated this conjecture only for $d=3$, however, it is quite natural to extend it to any $d$ (see $|\overline{P e t 14}|)$. To the best of our knowledge, this problem is unsolved for $d \geq 3$.

In the case $d=3$, L. Fejes Tóth [FT59 proved the conjecture for $n \leq 6$. He determined $S(n, 3)$ for $n \leq 5$ by direct calculation, and he obtained $S(6,3)$ using the recursive upper bound $S(n, 3) \leq n S(n-1,3) /(n-2)$ and the precise value of $S(5,3)$, see pp. 19 in FT59. The recursive upper bound and $S(6,3)$ together yield that $S(n, 3) \leq n(n-1) \pi / 5$ for all $n$. We further note that L. Fejes Tóth's recursive upper bound on $S(n, 3)$ can also be extended $S(n, d)$, that is, $S(n, d) \leq n S(n-1, d) /(n-2)$ for any meaningful $n$ and $d$.

The planar case is known, the value of $S(n, 2)$ is given in Theorem 2.2. Our main result in this chapter is an upper bound for $S(n, 3)$ summarized in the following theorem.

Theorem 2.1. Let $l_{1}, \ldots, l_{n}$ be lines in $\mathbb{R}^{3}$ which all pass through the origin. If we denote by $\varphi_{i j}$ the angle formed by $l_{i}$ and $l_{j}$, then

$$
\sum_{1 \leq i<j \leq n} \varphi_{i j} \leq\left\{\begin{array}{lll}
\frac{3}{2} k^{2} \cdot \frac{\pi}{2}, & \text { if } & n=2 k, \\
\frac{3}{2} k(k+1) \cdot \frac{\pi}{2}, & \text { if } & n=2 k+1 .
\end{array}\right.
$$

Notice that the bound in Theorem 2.1 is exactly $3 / 2$ times the bound in Theorem 2.2 . This factor comes from a projection averaging argument.

We note that the conjectured maximum for $d=3$ is asymptotically equal to $n^{2} \pi / 6$ as $n \rightarrow \infty$. The upper bound in Theorem 2.1 is asymptotically $3 n^{2} \pi / 16$ as $n \rightarrow \infty$, improving L. Fejes Tóth's bound, which is $n^{2} \pi / 5$ as $n \rightarrow \infty$.

We also note that if one could prove that $S(8,3)$ is equal to the conjectured value, then combining it with L. Fejes Tóth's recursive upper bound on $S(n, 3)$, one would obtain an upper bound on $S(n, 3)$ that is asymptotically equal to the one in Theorem 2.1. However, proving the optimality of a configuration with a specific number of lines, even as small as 8 , is notoriously difficult.

After our paper $|\overline{F V Z 16 a}|$ had appeared, the upper bound was improved by Bilyk and Matzke [BM19]. They showed that in any dimension the sum of the angles is asymptotically at most $\left(\frac{\pi}{4}-\frac{69}{100 d}\right) n^{2}$, which for $d=3$ yields a slightly better upper bound since $\frac{\pi}{4}-\frac{69}{300}=0.555398 \ldots<0.589048 \ldots=\frac{3 \pi}{16}$.

For comparison, we mention that the related problem, in which one seeks the maximum of the sum of the angles of $n$ rays emanating from the origin of $\mathbb{R}^{d}$, is solved for any $d$ 
and $n$. This is the same question as to maximize the sum of the mutual spherical distances of $n$ points on the sphere, or the sum of the pairwise angles of $n$ concurrent directed lines. This problem was also posed in the same paper of L. Fejes Tóth [FT59 for $d=3$. The 3-dimensional problem was fully solved as of 1965, see [Fro53, FT59, Spe60, Lar62, Nie65. The proof of Nielsen Nie65 uses a projection averaging argument. We note that this argument can be modified so as to obtain a solution of the general case of the problem for every $n$ and $d$. Our proof of Theorem 2.1 also uses this projection averaging idea, however, the details are much more intricate due to the different behaviour of the angles of undirected lines. We note that the undirected version (that is, the one we study in this chapter) can also be considered as a maximization problem on the elliptic plane.

One of the motivations for these arrangement problems on the sphere (and also in the ball) comes from physics and chemistry, where, for example, the points may represent charged particles that mutually repel each other. One is interested in finding the equilibra, or (locally) minimal energy positions of such point systems. The various settings, with regards to functions that one wants to maximize or minimize, may correspond to different forces between atoms, molecules, or other particles.

\subsection{The planar case}

Before we prove Theorem 2.1, we solve the problem in the plane. This result is probably known Pet14], however, we were unable to find any other reference, thus, we decided to include a short proof for the sake of completeness. The related problem for rays in the plane was analysed by Jiang Jia08 in 2008. He reproved the known upper bound and gave a full description of the extremal configurations in terms of balanced set of vectors.

We say that a line $l^{\prime}$ is to the right of $l$ if $l^{\prime}$ is obtained from $l$ by a rotation about the origin with angle $\alpha$, where $-\pi / 2<\alpha<0$. Similarly, if $0<\alpha<\pi / 2$, then $l^{\prime}$ is to the left of $l$. If $l^{\prime}=l$ or $l^{\prime}$ is perpendicular to $l$, then $l^{\prime}$ is neither to the left nor to the right of $l$. We say that a configuration $l_{1}, \ldots, l_{n}$ of $n$ lines is balanced if for any line $l \neq l_{1}, \ldots, l_{n}$ the number of lines to the left of $l$ and the number of lines to the right of $l$ differ by at most 1 . We remark that Jiang defined balanced systems of vectors in Jia08. Our definition of a balanced configuration of lines is similar to but not the same as that of Jiang.

Theorem 2.2. Let $l_{1}, \ldots, l_{n}$ be lines in $\mathbb{R}^{2}$ which all pass through the origin. If we denote 
by $\varphi_{i j}$ the angle formed by $l_{i}$ and $l_{j}$, then

$$
\sum_{1 \leq i<j \leq n} \varphi_{i j} \leq\left\{\begin{array}{lll}
k^{2} \cdot \frac{\pi}{2}, & \text { if } & n=2 k, \\
k(k+1) \cdot \frac{\pi}{2}, & \text { if } & n=2 k+1 .
\end{array}\right.
$$

Equality holds if, and only if, $l_{1}, \ldots, l_{n}$ is balanced.

Proof. The idea of the proof is similar to that of Jiang [Jia08, Theorem 1]. Note that a simple compactness argument guarantees that the maximum of the angle sum exists, and it is attained by some configuration.

Observe that if $l$ and $l^{\prime}$ are two perpendicular lines and $l^{\prime \prime}$ is an arbitrary third line, then the angle sum determined by $l, l^{\prime}$, and $l^{\prime \prime}$ is always $\pi$. This implies that if we have a perpendicular pair in a configuration of lines, then the pair can be freely rotated about the origin while the total sum of the angles remains unchanged.

Let $k=\lfloor n / 2\rfloor$, then $n=2 k$ or $n=2 k+1$. We are going to show that any configuration of $n$ lines can be continuously transformed, so that it is the disjoint union of $k$ perpendicular pairs (and possibly one remaining line in arbitrary position) and the angle sum does not decrease during the transformation. This clearly proves Theorem 2.2 .

Assume that $\left(l_{1}, l_{2}\right), \ldots,\left(l_{2 m-1}, l_{2 m}\right), m<k$ is a maximal set of pairwise disjoint perpendicular pairs in $l_{1}, \ldots, l_{n}$. During the transformation we will keep each already existing perpendicular pair. By the above observation, we may disregard these pairs as the angle sum of $l_{1}, \ldots, l_{n}$ is independent of their positions.

Let $l_{n}$ be vertical (it coincides with the $y$-axis), see Figure 2.1. By symmetry, we may clearly assume that there are at least as many lines to the right of $l_{n}$ as to the left. The case $l_{2 m+1}=l_{2 m+2}=\ldots=l_{n}$ being obvious, we may assume that there is at least one line to the right of $l_{n}$.

Observe that rotating $l_{n}$ by a small positive angle $\varepsilon>0$, the sum of the angles in $l_{1}, \ldots, l_{n}$ does not decrease. Thus, we may rotate $l_{n}$ until it becomes perpendicular to a line on its right-hand side. In this way, we have created a new perpendicular pair that is disjoint from $\left(l_{1}, l_{2}\right), \ldots,\left(l_{2 m-1}, l_{2 m}\right)$. This completes the proof of Theorem 2.2 .

We only sketch the analysis of the equality case. It is clear that if equality holds then the configuration of lines must be balanced. One can see that if $n=2 k$, then a balanced configuration of $n$ lines consists of $k$ pairs of perpendicular lines. On the other hand, a balanced configuration of $n=2 k+1$ lines, similarly as in the proof of the inequality, can be continuously transformed into a disjoint union of $k$ perpendicular pairs of lines and one remaining line in arbitrary position such that the angle sum does not change during the transformation. The details are left to the reader. This yields that for a fixed $n$ the 


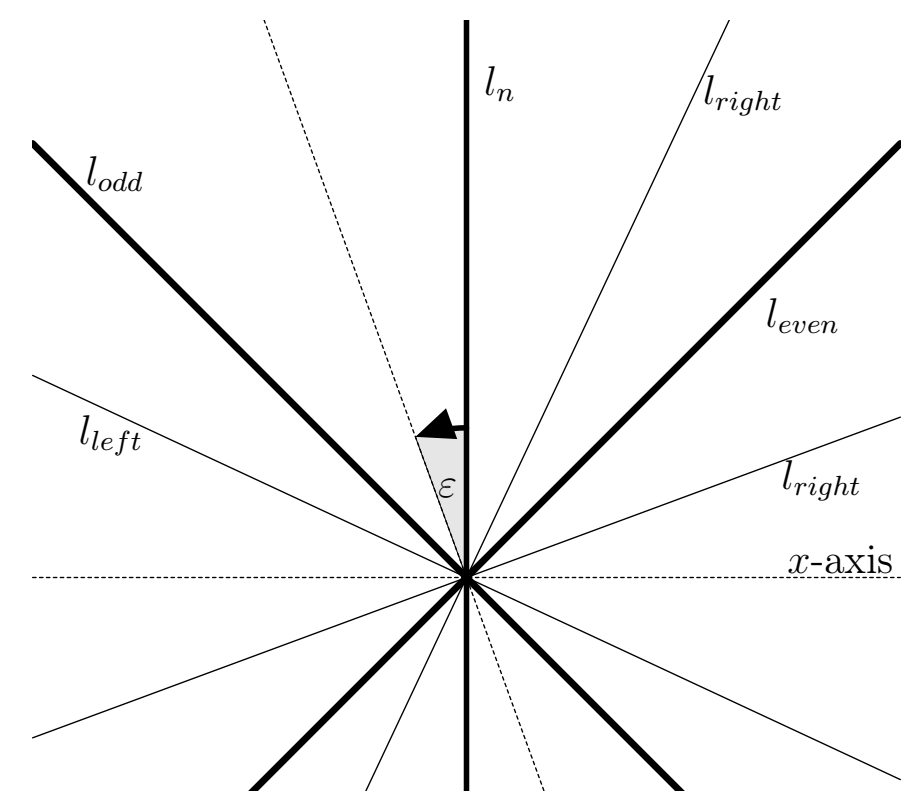

Figure 2.1: Rotating $l_{1}$

angle sum is the same in any balanced configuration of $n$ lines. This finishes the proof of the equality case.

\subsection{Proof of Theorem 2.1}

Let $S^{2}$ be the unit sphere of $\mathbb{R}^{3}$ centred at the origin. We denote the Euclidean scalar product by $\langle\cdot, \cdot\rangle$ and the induced norm by $|\cdot|$. For $\mathbf{u}, \mathbf{v} \in S^{2}$, we introduce $\mathbf{v}^{\mathbf{u}}=(\mathbf{u} \times \mathbf{v}) \times \mathbf{u}$, which is the component of $\mathbf{v}$ perpendicular to $\mathbf{u}$. Let $\mathbf{v}_{1}, \mathbf{v}_{2} \in S^{2}$, and let $\varphi=\angle\left(\mathbf{v}_{\mathbf{1}}, \mathbf{v}_{\mathbf{2}}\right)$ denote the angle formed by $\mathbf{v}_{1}, \mathbf{v}_{2}$. Introduce $\varphi^{\mathbf{u}}=\varphi^{\mathbf{u}}\left(\mathbf{v}_{1}, \mathbf{v}_{2}\right)$ for the angle formed by $\mathbf{v}_{1}^{\mathbf{u}}$ and $\mathbf{v}_{2}^{\mathbf{u}}$, and write

$$
\varphi_{*}^{\mathbf{u}}\left(\mathbf{v}_{1}, \mathbf{v}_{2}\right):=\min \left\{\varphi^{\mathbf{u}}\left(\mathbf{v}_{1}, \mathbf{v}_{2}\right), \pi-\varphi^{\mathbf{u}}\left(\mathbf{v}_{1}, \mathbf{v}_{2}\right)\right\}
$$

Let

$$
I\left(\mathbf{v}_{1}, \mathbf{v}_{2}\right)=I(\varphi):=\frac{1}{4 \pi} \int_{S^{2}} \varphi_{*}^{\mathbf{u}}\left(\mathbf{v}_{1}, \mathbf{v}_{2}\right) \mathrm{d} \mathbf{u},
$$

where the integration is with respect to the spherical Lebesgue measure. We will use the following lemma of Fáry [Fár49].

Lemma 2.3 (Fáry, Lemme 1. on pp. 133 in $[$ Fár49]).

$$
\varphi=\frac{1}{4 \pi} \int_{S^{2}} \varphi^{\mathbf{u}} \mathrm{d} \mathbf{u} \quad \text { for any } 0 \leq \varphi \leq \pi .
$$


We start the proof of Theorem 2.1 with two lemmas. The main aim of these lemmas is to verify that $I(\varphi) \geq 2 \varphi / 3$ for $0 \leq \varphi \leq \pi / 2$. From that fact Theorem 2.1 follows quickly through an integral averaging argument. As a first step, we calculate the exact values of $I(\varphi)$ at the endpoints of the interval at $\varphi=0$ and $\varphi=\pi / 2$.

Lemma 2.4. With the notation introduced above,

$$
I(0)=0 \quad \text { and } \quad I(\pi / 2)=\pi / 3 .
$$

Proof. The statement $I(0)=0$ is clearly true, so we need to calculate $I(\pi / 2)$ only. Let $\mathbf{v}_{1}=(1,0,0), \mathbf{v}_{2}=(0,1,0)$ and define $A=\left\{(x, y, z) \in S^{2} \mid x y \leq 0\right\}, A^{C}=\{(x, y, z) \in$ $\left.S^{2} \mid x y>0\right\}$, and $A_{+}^{C}=\left\{(x, y, z) \in S^{2} \mid x y>0, x>0\right\}$. Then the following holds

$$
\begin{aligned}
I(\pi / 2) & =\frac{1}{4 \pi} \int_{S^{2}} \varphi_{*}^{\mathbf{u}}\left(\mathbf{v}_{1}, \mathbf{v}_{2}\right) \mathrm{d} \mathbf{u}=\frac{1}{4 \pi} \int_{A} \varphi^{\mathbf{u}} \mathrm{d} \mathbf{u}+\frac{1}{4 \pi} \int_{A^{C}} \pi-\varphi^{\mathbf{u}} \mathrm{d} \mathbf{u} \\
& =\frac{1}{4 \pi} \int_{S^{2}} \varphi^{\mathbf{u}} \mathrm{d} \mathbf{u}-\frac{1}{4 \pi} \int_{A^{C}} \pi-2 \varphi^{\mathbf{u}} \mathrm{d} \mathbf{u} \\
& =\frac{\pi}{2}+\frac{1}{4 \pi} \int_{A^{C}} \pi \mathrm{d} \mathbf{u}-2 \cdot \frac{1}{4 \pi} \int_{A^{C}} \varphi^{\mathbf{u}} \mathrm{d} \mathbf{u} \\
& =\pi-4 \cdot \frac{1}{4 \pi} \int_{A_{+}^{C}} \varphi^{\mathbf{u}} \mathrm{d} \mathbf{u}
\end{aligned}
$$

using Lemma 2.3. Obviously, it is enough to show that

$$
\int_{A_{+}^{C}} \varphi^{\mathbf{u}} \mathrm{d} \mathbf{u}=\frac{2 \pi^{2}}{3} .
$$

Introduce the following spherical coordinates

$$
\mathbf{u}=\mathbf{u}(\theta, \psi)=(\sin \theta \cos \psi, \sin \theta \sin \psi, \cos \theta)
$$

where $0 \leq \theta \leq \pi$ and $0 \leq \psi \leq 2 \pi$. It is easily seen that

$$
\begin{aligned}
\varphi^{\mathbf{u}}\left(\mathbf{v}_{1}, \mathbf{v}_{2}\right) & =\arccos \frac{\left\langle\left(\mathbf{u} \times \mathbf{v}_{1}\right) \times \mathbf{u},\left(\mathbf{u} \times \mathbf{v}_{2}\right) \times \mathbf{u}\right\rangle}{\left|\left(\mathbf{u} \times \mathbf{v}_{1}\right) \times \mathbf{u}\right| \cdot\left|\left(\mathbf{u} \times \mathbf{v}_{2}\right) \times \mathbf{u}\right|} \\
& =\arccos \frac{\left\langle\mathbf{u} \times \mathbf{v}_{1}, \mathbf{u} \times \mathbf{v}_{2}\right\rangle}{\left|\mathbf{u} \times \mathbf{v}_{1}\right| \cdot\left|\mathbf{u} \times \mathbf{v}_{2}\right|}
\end{aligned}
$$

Straightforward calculations yield that $\mathbf{u} \times \mathbf{v}_{1}=(0, \cos \theta,-\sin \theta \sin \psi)$ and $\mathbf{u} \times \mathbf{v}_{2}=$ $(-\cos \theta, 0, \sin \theta \cos \psi)$, and hence

$$
\begin{aligned}
\left\langle\mathbf{u} \times \mathbf{v}_{1}, \mathbf{u} \times \mathbf{v}_{2}\right\rangle & =-\sin ^{2} \theta \sin \psi \cos \psi \\
\left|\mathbf{u} \times \mathbf{v}_{1}\right| \cdot\left|\mathbf{u} \times \mathbf{v}_{2}\right| & =\sqrt{\cos ^{2} \theta+\sin ^{4} \theta \sin ^{2} \psi \cos ^{2} \psi}
\end{aligned}
$$


Thus

$$
\begin{aligned}
\int_{A_{+}^{C}} \varphi^{\mathbf{u}} \mathrm{d} \mathbf{u} & =\int_{0}^{\pi} \int_{0}^{\pi / 2} \arccos \frac{-\sin ^{2} \theta \sin \psi \cos \psi}{\sqrt{\cos ^{2} \theta+\sin ^{4} \theta \sin ^{2} \psi \cos ^{2} \psi}} \cdot \sin \theta \mathrm{d} \psi \mathrm{d} \theta \\
& =2 \cdot \int_{0}^{\pi / 2} \int_{0}^{\pi / 2}\left(\pi-\arctan \frac{\cos \theta}{\sin ^{2} \theta \sin \psi \cos \psi}\right) \cdot \sin \theta \mathrm{d} \psi \mathrm{d} \theta \\
& =\pi^{2}-2 \int_{0}^{\pi / 2} \int_{0}^{\pi / 2} \arctan \frac{\cos \theta}{\sin ^{2} \theta \sin \psi \cos \psi} \cdot \sin \theta \mathrm{d} \theta \mathrm{d} \psi
\end{aligned}
$$

The inner integral in 2.1) can be directly calculated as follows. Let

$$
\begin{aligned}
g(\theta, \psi)= & \frac{1}{2} \tan \psi \cdot \ln (2 \cos (2 \theta) \cos (2 \psi)+2 \cos (2 \theta)-2 \cos (2 \psi)+6) \\
& +\frac{1}{2} \cot \psi \cdot \ln (-2 \cos (2 \theta) \cos (2 \psi)+2 \cos (2 \theta)+2 \cos (2 \psi)+6) \\
& -\cos \theta \cdot \arctan \frac{\cos \theta}{\sin ^{2} \theta \sin \psi \cos \psi}
\end{aligned}
$$

One can check by a tedious but straightforward calculation that

$$
\frac{\partial g(\theta, \psi)}{\partial \theta}=\arctan \frac{\cos \theta}{\sin ^{2} \theta \sin \psi \cos \psi} \cdot \sin \theta .
$$

Now, for a fixed $0<\psi<\pi / 2$, we obtain

$$
\begin{aligned}
\int_{0}^{\pi / 2} \arctan & \frac{\cos \theta}{\sin ^{2} \theta \sin \psi \cos \psi} \cdot \sin \theta \mathrm{d} \theta \\
= & \frac{1}{2} \tan \psi \cdot \ln (\cos (\pi-2 \psi)+\cos (\pi+2 \psi)-2 \cos (2 \psi)+4) \\
+ & \frac{1}{2} \cot \psi \cdot \ln (-\cos (\pi-2 \psi)-\cos (\pi+2 \psi)+2 \cos (2 \psi)+4) \\
& -\left[\frac{1}{2} \tan \psi \cdot \ln (\cos (-2 \psi)+\cos (2 \psi)-2 \cos (2 \psi)+8)\right. \\
& \left.\quad+\frac{1}{2} \cot \psi \cdot \ln (-\cos (-2 \psi)-\cos (2 \psi)+2 \cos (2 \psi)+8)-\pi / 2\right] \\
= & \frac{1}{2} \tan \psi \cdot \ln (4(1-\cos (2 \psi)))+\frac{1}{2} \cot \psi \cdot \ln (4(1+\cos (2 \psi))) \\
& +\pi / 2-\frac{\ln 8}{2}(\tan +\cot \psi) \\
= & \frac{1}{2}\left(\pi+\tan \psi \ln \left(\sin ^{2} \psi\right)+\cot \psi \ln \left(\cos ^{2} \psi\right)\right) \\
= & \frac{\pi}{2}+\tan \psi \ln (\sin \psi)+\cot \psi \ln (\cos \psi) .
\end{aligned}
$$


We turn to the outer integral in 2.1.

$$
\begin{aligned}
\int_{0}^{\pi / 2} & \int_{0}^{\pi / 2} \arctan \frac{\cos \theta}{\sin ^{2} \theta \sin \psi \cos \psi} \cdot \sin \theta \mathrm{d} \theta \mathrm{d} \psi \\
& =\int_{0}^{\pi / 2} \frac{\pi}{2}+\tan \psi \ln (\sin \psi)+\cot \psi \ln (\cos \psi) \mathrm{d} \psi \\
& =\frac{\pi^{2}}{4}+\int_{0}^{\pi / 2} \tan \psi \ln (\sin \psi) \mathrm{d} \psi+\int_{0}^{\pi / 2} \cot \psi \ln (\cos \psi) \mathrm{d} \psi
\end{aligned}
$$

Using the substitution $u=\sin \psi$ in the first integral and $u=\cos \psi$ in the second integral, we obtain that

$$
\int_{0}^{\pi / 2} \tan \psi \ln (\sin \psi) \mathrm{d} \psi=\int_{0}^{\pi / 2} \cot \psi \ln (\cos \psi) \mathrm{d} \psi=\int_{0}^{1} \frac{u \ln u}{1-u^{2}} \mathrm{~d} u .
$$

Integration by parts gives

$$
\int_{0}^{1} \frac{u \ln u}{1-u^{2}} \mathrm{~d} u=\left.\frac{-\ln u \ln \left(1-u^{2}\right)}{2}\right|_{0} ^{1}+\frac{1}{2} \int_{0}^{1} \frac{\ln \left(1-u^{2}\right)}{u} \mathrm{~d} u
$$

where $\left.\frac{-\ln u \ln \left(1-u^{2}\right)}{2}\right|_{0} ^{1}=0$ by L'Hospital's rule. Now, the substitution $x=u^{2}$ yields

$$
\begin{aligned}
\frac{1}{2} \int_{0}^{1} \frac{\ln \left(1-u^{2}\right)}{u} \mathrm{~d} u & =\frac{1}{4} \int_{0}^{1} \frac{\ln (1-x)}{x} \mathrm{~d} x=\frac{-1}{4} \int_{0}^{1} \frac{\operatorname{Li}_{1}(x)}{x} \mathrm{~d} x \\
& =\frac{-1}{4} \operatorname{Li}_{2}(1)=\frac{-\pi^{2}}{24}
\end{aligned}
$$

where in the last two steps we used the polylogarithm functions $\operatorname{Li}_{s}(z)$ and their wellknown properties. For more information on the polylogarithm functions we refer to [Zag89. This finishes the proof of Lemma 2.4.

Lemma 2.5. The function $I(\varphi)$ is concave on $[0, \pi / 2]$, and

$$
I(\varphi) \geq 2 \varphi / 3 \quad \text { for } \quad 0 \leq \varphi \leq \pi / 2
$$

Before we turn to the proof of Lemma 2.5, for the sake of completeness, we recall some definitions and a theorem from Bru64.

The function $f:[a, b] \rightarrow \mathbb{R}$ is superadditive on $[a, b]$ if for any positive $h<b-a$ and $x \in[a, b-h], f(a+h)-f(a) \leq f(x+h)-f(x)$, cf. Definition 2.2 on pp. 61 in Bru64. We call $f$ locally superadditive on $[a, b]$ if for every $x_{0} \in[a, b]$, there exist arbitrarily small neighbourhoods of $x_{0}$ on which $f$ is superadditive, cf. Definition 2.3 on pp. 62 in Bru64. 
Theorem 2.6 (Bruckner, Theorem 3.1. on pp. 62 in |Bru64|). Let $f$ be locally superadditive and differentiable on an interval $[a, b]$, with $f^{\prime}$ continuous almost everywhere in $[a, b]$. Then $f$ is convex.

Proof of Lemma 2.5. Obviously, $I(\varphi)$ is a continuously differentiable function of $\varphi$ on $[0, \pi / 2]$.

Fix $0 \leq \alpha \leq \beta \leq \pi / 2$, a small $0 \leq \delta \leq \pi / 2-\beta$, and a vector $\mathbf{u} \in S^{2}$. Let $\angle(\cdot, \cdot)$ denote the angle formed by two vectors. Choose four coplanar vectors $\mathbf{w}_{1}, \mathbf{w}_{2}, \mathbf{w}_{3}, \mathbf{w} \in S^{2}$ such that $\angle\left(\mathbf{w}_{1}, \mathbf{w}_{2}\right)=\alpha, \angle\left(\mathbf{w}_{1}, \mathbf{w}_{3}\right)=\beta, \angle\left(\mathbf{w}_{1}, \mathbf{w}\right)=\delta, \angle\left(\mathbf{w}, \mathbf{w}_{2}\right)=\alpha+\delta$, and $\angle\left(\mathbf{w}, \mathbf{w}_{3}\right)=$ $\beta+\delta$. As before, we use the abbreviations $\alpha^{\mathbf{u}}=\alpha^{\mathbf{u}}\left(\mathbf{w}_{1}, \mathbf{w}_{2}\right)$ and $\alpha_{*}^{\mathbf{u}}=\alpha_{*}^{\mathbf{u}}\left(\mathbf{w}_{1}, \mathbf{w}_{2}\right)$, and similarly for the other angles.

We claim that

$$
(\alpha+\delta)_{*}^{\mathbf{u}}-\alpha_{*}^{\mathbf{u}} \geq(\beta+\delta)_{*}^{\mathbf{u}}-\beta_{*}^{\mathbf{u}} .
$$

To prove (2.3), we write the left-hand side, and, respectively, the right-hand side as follows:

$$
(\alpha+\delta)_{*}^{\mathbf{u}}-\alpha_{*}^{\mathbf{u}}= \begin{cases}-\delta^{\mathbf{u}}, & \text { if } \quad \alpha^{\mathbf{u}}>\pi / 2, \\ \pi-2 \alpha^{\mathbf{u}}-\delta^{\mathbf{u}}, & \text { if } \quad \alpha^{\mathbf{u}} \leq \pi / 2 \text { and }(\alpha+\delta)^{\mathbf{u}}>\pi / 2, \\ \delta^{\mathbf{u}}, & \text { if } \quad(\alpha+\delta)^{\mathbf{u}} \leq \pi / 2\end{cases}
$$

and

$$
(\beta+\delta)_{*}^{\mathbf{u}}-\beta_{*}^{\mathbf{u}}= \begin{cases}-\delta^{\mathbf{u}}, & \text { if } \quad \beta^{\mathbf{u}}>\pi / 2, \\ \pi-2 \beta^{\mathbf{u}}-\delta^{\mathbf{u}}, & \text { if } \quad \beta^{\mathbf{u}} \leq \pi / 2 \text { and }(\beta+\delta)^{\mathbf{u}}>\pi / 2, \\ \delta^{\mathbf{u}}, & \text { if } \quad(\beta+\delta)^{\mathbf{u}} \leq \pi / 2 .\end{cases}
$$

To show (2.3), we consider three cases as in (2.4). If $\alpha^{\mathbf{u}}>\pi / 2$, then $\beta^{\mathbf{u}}>\pi / 2$, and equality holds in (2.3). If $\alpha^{\mathbf{u}} \leq \pi / 2$ and $(\alpha+\delta)^{\mathbf{u}}>\pi / 2$, then $(\beta+\delta)^{\mathbf{u}}>\pi / 2$, and either the first or the second case applies in (2.5). Now, $\pi-2 \alpha^{\mathbf{u}}-\delta^{\mathbf{u}} \geq-\delta^{\mathbf{u}}$ is equivalent to $\alpha^{\mathbf{u}} \leq \pi / 2$, thus it holds true. Also, from $\alpha^{\mathbf{u}} \leq \beta^{\mathbf{u}}$, it follows that $\pi-2 \alpha^{\mathbf{u}}-\delta^{\mathbf{u}} \geq \pi-2 \beta^{\mathbf{u}}-\delta^{\mathbf{u}}$, as claimed. The only case that remains to be checked is when $(\alpha+\delta)^{\mathbf{u}} \leq \pi / 2$, and thus $(\alpha+\delta)_{*}^{\mathbf{u}}-\alpha_{*}^{\mathbf{u}}=\delta^{\mathbf{u}}$. If, in $(2.5)$, the first or the third case applies, then the inequality in $(2.3)$ clearly holds. Thus, we only need to consider the case when $(\beta+\delta)^{\mathbf{u}}>\pi / 2$. Then $\delta^{\mathbf{u}}>\pi-2 \beta^{\mathbf{u}}-\delta^{\mathbf{u}}$, which finishes the proof of (2.3).

Since (2.3) holds true for any unit vector $\mathbf{u} \in S^{2}$, it follows that for any $0 \leq \alpha \leq \beta \leq$ $\pi / 2$, and $0 \leq \delta \leq \pi / 2-\beta$, we have

$$
I(\alpha+\delta)-I(\alpha) \geq I(\beta+\delta)-I(\beta)
$$


Hence $-I$ is superadditive on any subinterval of $[0, \pi / 2]$, and thus it satisfies all the conditions of Theorem 2.6 on the interval $[0, \pi / 2]$. It follows that $-I$ is convex, and so $I$ is concave, as stated. Finally, the inequality 2.2 is a simple consequence of Lemma 2.4 and of the concavity of $I$. This completes the proof of Lemma 2.5

Proof of Theorem 2.1. Consider the lines $l_{1}, \ldots, l_{n}$, and a vector $\mathbf{u} \in S^{2}$. Let $S$ be the plane through the origin with normal vector $\mathbf{u}$, and let $l_{i}^{\prime}$ denote the orthogonal projection of the line $l_{i}$ onto $S$. We denote by $\varphi_{i j}^{\mathbf{u}}$ the (non-obtuse) angle formed by $l_{i}^{\prime}$ and $l_{j}^{\prime}$. Applying 2.2), we obtain that

$$
\begin{aligned}
\frac{1}{4 \pi} \int_{S^{2}} \sum_{1 \leq i<j \leq n} \varphi_{i j}^{\mathbf{u}} \mathrm{d} u & =\sum_{1 \leq i<j \leq n} \frac{1}{4 \pi} \int_{S^{2}} \varphi_{i j}^{\mathbf{u}} \mathrm{d} u \\
& \geq \sum_{1 \leq i<j \leq n} 2 \varphi_{i j} / 3=\frac{2}{3} \sum_{1 \leq i<j \leq n} \varphi_{i j} .
\end{aligned}
$$

Therefore, there exists a $\mathbf{u}_{0} \in S^{2}$ with the property

$$
\sum_{1 \leq i<j \leq n} \varphi_{i j}^{\mathbf{u}_{0}} \geq \frac{2}{3} \sum_{1 \leq i<j \leq n} \varphi_{i j}
$$

Finally, Theorem 2.2 implies that

$$
\sum_{1 \leq i<j \leq n} \varphi_{i j}^{\mathbf{u}_{0}} \leq\left\{\begin{array}{lll}
k^{2} \cdot \frac{\pi}{2}, & \text { if } & n=2 k \\
k(k+1) \cdot \frac{\pi}{2}, & \text { if } & n=2 k+1
\end{array}\right.
$$

which completes the proof of Theorem 2.1.

And thus, we successfully gave a better upper bound on the angle-sum of lines in 3 dimensions. 


\section{Chapter 3}

\section{Covering the sphere by equal zones}

\subsection{Introduction}

This chapter is based on the joint paper $\overline{\text { FVZ16b }}$ by F. Fodor, V. Vígh and the author of this thesis. The question considered in this part of the dissertation belongs to the family of problems about arrangements of great circles (and great subspheres) on the sphere.

Let $S^{2}$ denote the unit sphere in 3-dimensional Euclidean space $\mathbb{R}^{3}$ centred at the origin $o$. The spherical distance $d_{s}(x, y)$ of two points $x, y \in S^{2}$ is defined as the length of a (shorter) geodesic arc connecting $x$ and $y$ on $S^{2}$, or equivalently, the central angle $\angle x o y$ spanned by $x$ and $y$. Following L. Fejes Tóth [FT73], a zone $Z$ of half-width $w$ in $S^{2}$ is the parallel domain of radius $w$ of a great circle $C$, that is,

$$
Z(C, w):=\left\{x \in S^{2} \mid d_{s}(x, C) \leq w\right\}
$$

Alternately, one can also define the zone $Z(C, w)$ as the part of the sphere $S^{2}$ between two $o$-symmetric parallel planes whose distance is $2 \sin w$. We call $C$ the central great circle of $Z$.

In this chapter, we investigate the following problem.

Problem 3.1 (L. Fejes Tóth [FT73). For a given n, find the smallest number $w_{n}$ such that one can cover $S^{2}$ with $n$ zones of half-width $w_{n}$. Find also the optimal configurations of zones that realize the optimal coverings.

The problem was originally phrased in a different way in [FT73]: Minimize the maximum of the inradii of the regions into which the $n$ great circles divide $S^{2}$. This is clearly equivalent to the above formulation.

We note that in the same paper [FT73 L. Fejes Tóth also asked the analogous question with not necessarily congruent zones, and conjectured that the sum of the half-widths of 
the zones that can cover $S^{2}$ is always at least $\pi / 2$. Furthermore, L. Fejes Tóth FT73 posed the question: what is the minimum of the sum of the half-widths of $n$ (not necessarily congruent) zones that can cover a spherically convex disc on $S^{2}$ ? Here, a compact set in $S^{2}$ with non-empty interior is a spherically convex disc if it is contained in an open hemisphere and together with any two of its points it also contains the shorter great circular arc connecting the points.

Notice that although a zone on the sphere is the intersection of a Euclidean plank and the sphere, the zone itself is not spherically convex. In fact, it is bounded by small circles. This is a source of various difficulties when dealing with zones.

These questions are somewhat similar to the classical plank problem of Tarski [Tar32]. According to the original conjecture of Tarski, if a convex body $K \subseteq \mathbb{R}^{d}$ is covered by a finite number of planks (the part of space between two parallel hyperplanes whose distance is the width of the plank), then the sum of their widths is not less than the minimal width of $K$. The minimal width of $K$ is the minimum of the widths of planks that cover $K$. This form of Tarski's conjecture was proved by Bang [Ban50, Ban51]. We refer to the paper Bez13 by K. Bezdek for a recent survey on this topic. However, this similarity between Tarski's problem and the zone covering problem of L. Fejes Tóth is limited by the fact that the zones are not spherically convex, and by the different behaviour of the width of spherically convex bodies.

L. Fejes Tóth formulated the following conjecture about the sphere and zones:

Conjecture 3.2 (L. Fejes Tóth $\mid$ FT73]). For $n \geq 1, w_{n}=\pi /(2 n)$.

One can get some trivial upper and lower bounds for $w_{n}$ as follows. It is clear that $w_{n} \leq \pi /(2 n)$ since $n$ zones of half-width $\pi /(2 n)$, whose central great circles all pass through a pair of antipodal points of $S^{2}$ and which are distributed evenly, cover $S^{2}$. On the other hand, as the zones must cover $S^{2}$, the sum of their areas must be at least (actually, greater than) $4 \pi$, that is, $w_{n}>\arcsin (1 / n)$.

Rosta Ros72 proved that $w_{3}=\pi / 6$, and that the unique optimal configuration consists of three zones whose central great circles pass through two antipodal points of $S^{2}$ and are distributed evenly. Linhart Lin74 showed that $w_{4}=\pi / 8$, and the unique optimal configuration is similar to the one for $n=3$.

In our paper (cf. FVZ16b, Remark 3, pp. 487-488]) we formulated the natural generalization of the problem for $d$ dimensions that seeks the minimum width $w(d, n)$ of $n$ congruent zones on the $d$-dimensional unit sphere $S^{d-1}$ that can form a covering. Although we did venture to formulate a conjecture, we calculated that $w(d, 3)=\pi / 6$ for all $d \geq 3$. 
In 2017, Jiang and Polyanskii [JP17] proved the original conjecture of L. Fejes Tóth for $d=3$, and also its generalized version in $d$ dimensions. They also proved the following spherical analogue of Tarski's plank problem for symmetric bodies that originates from the same paper of L. Fejes Tóth |FT73]: If a centrally symmetric convex body on the sphere is covered with a finite number of zones of total width $w$ then the body can also be covered by a single zone of width $w$. Their idea of the proof is inspired by Bang's lemma and the result of Goodman and Goodman GG45.

The rest of this chapter is organized as follows. In Section 3.2, we determine the area of the intersection of two congruent zones as a function of their half-widths and the angle of their central great circles under some suitable restrictions (that the intersection is not connected). In Section 3.3, we use the currently known best upper bounds for the Tammes problem (a classical packing problem on the sphere, see the details later) in which one seeks the maximum of the minimal pairwise spherical distances of $n$ points in $S^{2}$. Subsequently, we estimate from above the contribution of the zones in an optimal covering one-by-one. Adding up these estimated contributions, we obtain a lower bound for $w_{n}$. The main result of this chapter is stated in Theorem 3.6. The reason why the main theorem is only phrased at the end of the chapter is that its formulation requires a number of definitions and notations that are introduced only in the argument. We finish the chapter by calculating some numerical values of the established lower bound and comparing them with the trivial and conjectured bounds.

\subsection{Intersection of two zones}

We start with the following simple observation. Consider two zones $Z_{1}$ and $Z_{2}$ of halfwidth $w$ whose central great circles make an angle $\alpha$. If $\alpha \geq 2 w$, then the intersection of $Z_{1}$ and $Z_{2}$ is the union of two disjoint congruent spherical domains. These domains are symmetric to each other with respect to $o$, and they resemble to a rhombus which is bounded by four small circular arcs of equal (spherical) length. If $\alpha \leq 2 w$, then the intersection is a connected, band-like domain. Let $2 F(w, \alpha)$ denote the area of $Z_{1} \cap Z_{2}$.

Lemma 3.3. Let $0 \leq w \leq \pi / 4$ and $2 w \leq \alpha \leq \pi / 2$. Then

$$
\begin{aligned}
F(w, \alpha)=2 \pi & +4 \sin w \arcsin \left(\frac{1-\cos \alpha}{\cot w \sin \alpha}\right)+4 \sin w \arcsin \left(\frac{1+\cos \alpha}{\cot w \sin \alpha}\right) \\
& -2 \arccos \left(\frac{\cos \alpha-\sin ^{2} w}{\cos ^{2} w}\right)-2 \arccos \left(\frac{-\cos \alpha-\sin ^{2} w}{\cos ^{2} w}\right) .
\end{aligned}
$$

Moreover, $F(w, \alpha)$ is a monotonically decreasing function of $\alpha$ in the interval $[0, \pi / 2]$. 
Proof. First, we prove (3.1). Let $Z_{1}$ be the zone of half-width $w$ whose central great circle $C_{1}$ is the intersection of the $x y$-plane with $S^{2}$. Let $c_{1}$ and $c_{3}$ denote the small circles which bound $Z_{1}$ such that $c_{1}$ is contained in the closed half-space $z \geq 0$.

Let $Z_{2}$ be the zone of half-width $w$ whose central great circle $C_{2}$ is the intersection of $S^{2}$ with the plane which contains the $y$-axis and which makes an angle $\alpha$ with the $x y$-plane as shown in Figure 3.1. Let $c_{2}$ and $c_{4}$ be the small circles bounding $Z_{2}$, cf. Figure 3.1 .

The intersection $Z_{1} \cap Z_{2}$ is the union of two connected components $R_{1}$ and $R_{2}$. Assume that $R_{1}$ is contained in the closed half-space $y \leq 0$. Let $c_{i}^{\prime}, i=1, \ldots, 4$ denote the arc of $c_{i}$ that bounds $R_{1}$. Observe that $c_{1}^{\prime}, \ldots, c_{4}^{\prime}$ are of equal length; we denote their common arc length by $l(w, \alpha)$. The radii of $c_{1}, \ldots, c_{4}$ are all equal to $\cos w$.

Assume that the boundary $\partial R_{1}$ of $R_{1}$ is oriented such that the small circular arcs follow each other in the cyclic order $c_{1}^{\prime}, c_{2}^{\prime}, c_{3}^{\prime}, c_{4}^{\prime}$. For $i \in\{1, \ldots, 4\}$, let $\varphi_{i}(w, \alpha)$ denote the turning angle of $\partial R_{1}$ at the intersection point of $c_{i}^{\prime}$ and $c_{i+1}^{\prime}$ with the convention that $c_{5}=c_{1}$. Notice that the signed geodesic curvature of $\partial R_{1}$ (in its smooth points) is equal to $-\tan w$.

By the Gauss-Bonnet Theorem it holds that

$$
F(w, \alpha)=2 \pi+4 \tan w \cdot l(w, \alpha)-\sum_{i=1}^{4} \varphi_{i}(w, \alpha) .
$$

Next, we calculate the $\varphi_{i}(w, \alpha)$. Note that $\varphi_{i}(w, \alpha)=\varphi_{i+2}(w, \alpha)$ for $i=1,2$.

Let $\Pi_{1}$ be the plane whose normal vector is $u_{1}=(0,0,1)$ and contains the point $(0,0, \sin w)$. Let $\Pi_{2}$ be the plane which we get by rotating $\Pi_{1}$ around the $y$-axis by angle $\alpha$ so its normal vector is $u_{2}=(-\sin \alpha, 0, \cos \alpha)$, see Figure 3.1 . Note that $S^{2} \cap \Pi_{1}=c_{1}$ and $S^{2} \cap \Pi_{2}=c_{2}$.

$$
\begin{aligned}
& \Pi_{1}: \quad z=\sin w \\
& \Pi_{2}: \quad-x \sin \alpha+z \cos \alpha=\sin w
\end{aligned}
$$

Now let $L_{1}=\Pi_{1} \cap \Pi_{2}$ and $L_{1} \cap S^{2}=\left\{l_{1}, l_{1}^{\prime}\right\}$, such that $l_{1}$ has negative $y$-coordinate. Then

$$
l_{1}=\left(\sin w(\cot \alpha-\csc \alpha),-\sqrt{1-\sin ^{2} w\left(1+(\cot \alpha-\csc \alpha)^{2}\right)}, \sin w\right) .
$$

Let $\Pi$ be the plane that is tangent to $S^{2}$ in $l_{1}$, and let $E_{1}=\Pi_{1} \cap \Pi$ and $E_{2}=\Pi_{2} \cap \Pi$. Then $\varphi_{1}$ is one of the angles made by $E_{1}$ and $E_{2}$. Let $v_{1}=l_{1} \times u_{1}$ and $v_{2}=l_{1} \times u_{2}$. Then $v_{1}$ and $v_{2}$ are vectors parallel to $E_{1}$ and $E_{2}$, respectively, such that their orientations agree with that of $\partial R_{1}$.

$$
v_{1}=\left(-\sqrt{1-\sin ^{2} w\left(1+(\cot \alpha-\csc \alpha)^{2}\right)},-\sin w(\cot \alpha-\csc \alpha), 0\right)
$$




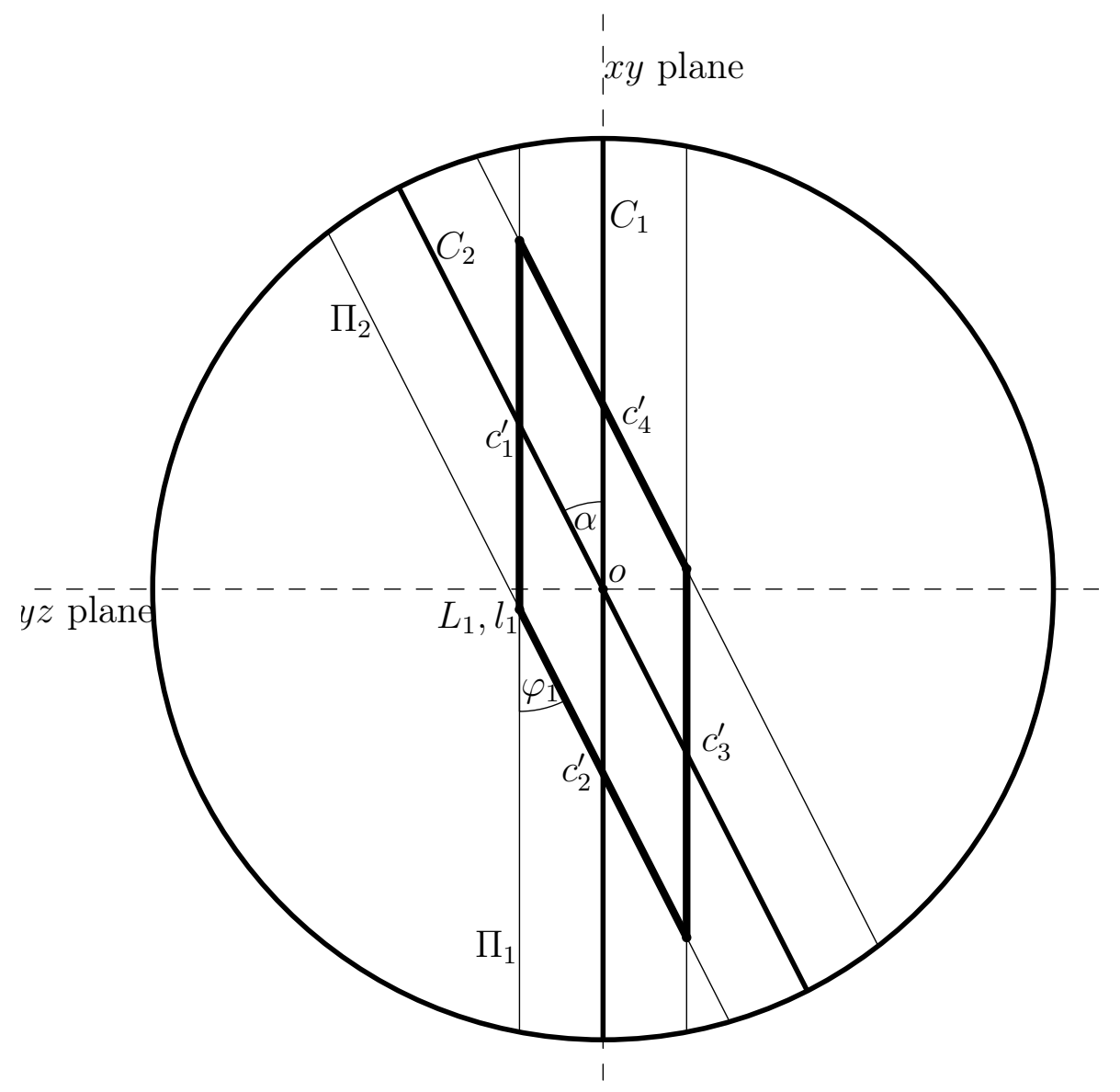

Figure 3.1: Orthogonal projection onto the $x z$ plane 


$$
\begin{aligned}
v_{2} & =\left(-\cos \alpha \sqrt{1-\sin ^{2} w\left(1+(\cot \alpha-\csc \alpha)^{2}\right.}\right),-\cos \alpha \sin w(\cot \alpha-\csc \alpha)- \\
& \left.-\sin \alpha \sin w,-\sin \alpha \sqrt{1-\sin ^{2} w\left(1+(\cot \alpha-\csc \alpha)^{2}\right)}\right) .
\end{aligned}
$$

We only need to calculate the lengths of $v_{1}$ and $v_{2}$ and their scalar product. By routine calculations we obtain

$$
\varphi_{1}=\arccos \frac{\left\langle v_{1}, v_{2}\right\rangle}{\left|v_{1}\right|\left|v_{2}\right|}=\arccos \left(\frac{\cos \alpha-\sin ^{2} w}{\cos ^{2} w}\right) .
$$

The angle $\varphi_{2}$ can be evaluated similarly; one only needs to write $\pi-\alpha$ in place of $\alpha$ in the above calculations. Then

$$
\varphi_{2}=\arccos \left(\frac{-\cos \alpha-\sin ^{2} w}{\cos ^{2} w}\right) .
$$

To finish the calculation, we need to find $l(w, \alpha)$. Let $l_{i}:=c_{i}^{\prime} \cap c_{i+1}^{\prime}$ for $i=1,2,3,4$ with $c_{5}^{\prime}=c_{1}^{\prime}$. Let $d_{i}, i=1, \ldots, 4$ be the absolute value of the $y$-coordinate of $l_{i}$. Simple trigonometry shows that

$$
d_{1}=\frac{1-\cos \alpha}{\cot w \sin \alpha}
$$

and

$$
d_{4}=\frac{1+\cos \alpha}{\cot w \sin \alpha}
$$

Then the length of $c_{1}^{\prime}$ is equal to the following

$$
\begin{aligned}
l(w, \alpha) & =\cos w \arcsin d_{1}+\cos w \arcsin d_{4} \\
& =\cos w \arcsin \left(\frac{1-\cos \alpha}{\cot w \sin \alpha}\right)+\cos w \arcsin \left(\frac{1+\cos \alpha}{\cot w \sin \alpha}\right) .
\end{aligned}
$$

In summary,

$$
\begin{aligned}
F(w, \alpha)=2 \pi & +4 \sin (w) \arcsin (\tan (w)(\csc (\alpha)+\cot (\alpha))) \\
& +4 \sin (w) \arcsin (\tan (w)(\csc (\alpha)-\cot (\alpha))) \\
& -2 \arccos \left(\frac{\cos (\alpha)-\sin ^{2}(w)}{\cos ^{2}(w)}\right) \\
& -2 \arccos \left(\frac{\cos (\alpha)+\sin ^{2}(w)}{-\cos ^{2}(w)}\right)
\end{aligned}
$$

Finally, we prove that $F$ is monotonically decreasing in $\alpha$. This is obvious in the interval $[0,2 w]$.

Let $\alpha \geq 2 w$ and $\varepsilon>0$ be sufficiently small with $\alpha+\varepsilon \leq \pi / 2$. Consider the spherical "rhombus" $R_{1}^{*}$ which is obtained as the intersection of $Z_{1}$ and another zone $Z_{2}^{*}$ of halfwidth $w$ whose central great circle $C_{2}^{*}$ is the intersection of $S^{2}$ with the plane which 
contains the $y$-axis and which makes an angle $\alpha+\varepsilon$ with the $x y$-plane, similarly as for $Z_{2}$ above. Let $F_{1}$ be the area of $R_{1} \backslash R_{1}^{*}$ and $F_{1}^{*}$ be the area of $R_{1}^{*} \backslash R_{1}$. For the monotonicity of $F(w, \alpha)$ in $\alpha$, we only need to show that $F_{1}>F_{1}^{*}$.

The region $R_{1} \backslash R_{1}^{*}$ consists of two disjoint congruent connected domains (in fact, two triangular regions bounded by arcs of small circles). Note that one such region, say $P$, is fully contained in the positive hemisphere of $S^{2}(z \geq 0)$, and the other region is contained in the negative hemisphere $(z \leq 0)$. Similarly, let $Q$ be the one of the two connected, congruent and disjoint regions whose union is $R_{1}^{*} \backslash R_{1}$ and which has a common (boundary) point with $P$. Let $q=P \cap Q$, then $q$ has positive $z$-coordinate. It easily follows from the position of $q$ that the arc $c_{2} \cap Q$ is longer than $c_{2} \cap P$, and, similarly, $c_{2}^{*} \cap Q$ is longer than $c_{2}^{*} \cap P$, so the area of $Q$ is larger than the area of $P$, which completes the proof of the Lemma.

Remark 3.4. Let $Z_{1}$ and $Z_{2}$ be two zones of half-width $w \in(0, \pi / 4]$ which make an angle $\alpha$. Then it is clear that the area of $Z_{1} \cup Z_{2}$ is a monotonically increasing function of $\alpha$ for $\alpha \in[0,2 w]$.

\subsection{A lower bound for the minimal width}

We start this section by discussing the Tammes problem, which belongs to the family of questions about arrangements of points on the sphere that we mentioned in the previous chapter of this dissertation. For an integer $n \geq 3$, let $d_{n}$ denote the maximum of the minimal pairwise (spherical) distances of $n$ points on the unit sphere $S^{2}$. Finding $d_{n}$ is a long-standing problem of discrete geometry which goes back to the Dutch botanist Tammes (1930) (see [Tam30]). He was originally interested in the beautifully symmetric arrangements of orifices on grains of pollen. This is a notoriously hard problem which is solved only for a few special (small) values of $n$, and for other $n$ there are only some general bounds. More precisely, as of now, the exact value of $d_{n}$ is only known in the following cases, see Table 3.1 below.

Alternate proofs were given by Hárs $[$ Hár86 for the case $n=10$, and by Böröczky Bör83 for the case $n=11$.

For $n \geq 3$, L. Fejes Tóth (see [FT72]) proved the following upper estimate

$$
d_{n} \leq \tilde{\delta}_{n}:=\arccos \left(\frac{\cot ^{2}\left(\frac{n}{n-2} \frac{\pi}{6}\right)-1}{2}\right),
$$

where equality holds exactly in the cases $n=3,4,6,12$ (see table below). Moreover, $\lim _{n \rightarrow \infty} \tilde{\delta}_{n} / d_{n}=1$, that is, $\tilde{\delta}_{n}$ provides an exact asymptotic upper bound for $d_{n}$ as $n \rightarrow \infty$. 


\begin{tabular}{|c|c|c|}
\hline$n$ & $d_{n}$ & \\
\hline 3 & $2 \pi / 3$ & L. Fejes Tóth |FT43 \\
\hline 4 & 1.91063 & L. Fejes Tóth $\mid$ FT43 \\
\hline 5 & $\pi / 2$ & Schütte, van der Waerden SvdW51 \\
\hline 6 & $\pi / 2$ & L. Fejes Tóth $\mid$ FT43 \\
\hline 7 & 1.35908 & Schütte, van der Waerden SvdW51 \\
\hline 8 & 1.30653 & Schütte, van der Waerden SvdW51 \\
\hline 9 & 1.23096 & Schütte, van der Waerden SvdW51 \\
\hline 10 & 1.15448 & Danzer Dan86 \\
\hline 11 & 1.10715 & Danzer Dan86 \\
\hline 12 & 1.10715 & L. Fejes Tóth $\mathbf{\text { FT43 }}$ \\
\hline 13 & 0.99722 & Musin, Tarasov MT12 \\
\hline 14 & 0.97164 & Musin, Tarasov MT15 \\
\hline 24 & 0.76255 & Robinson Rob61 \\
\hline
\end{tabular}

Table 3.1: Known (approximate) values of $d_{n}$

Robinson Rob61 improved the upper estimate 3.4 of L. Fejes Tóth as follows. Assume that the pairwise distances between the $n$ points on the sphere are all at least $a$ where $0<a<\arctan 2$. Let $\Delta_{1}(a)$ denote the area and $\tilde{\alpha}$ the internal angle of an equilateral spherical triangle with side length $a$, and $\Delta_{2}(a)$ denote the area of a spherical triangle with two sides of length $a$ making an angle of $2 \pi-4 \tilde{\alpha}$. Let $\delta_{n}$ be the unique solution of the equation $4 n \Delta_{1}(a)+(2 n-12) \Delta_{2}(a)-12 \pi=0$. Then (cf. Rob61]) $d_{n} \leq \delta_{n} \leq \tilde{\delta}_{n}$ for $n \geq 13$.

Let $d_{n}^{*}:=\min \left\{\pi / 2, d_{n}\right\}$ for $n \geq 2$, and let

$$
\delta_{n}^{*}:= \begin{cases}d_{n}^{*} & \text { for } 3 \leq n \leq 14 \text { and } n=24 \\ \delta_{n} & \text { otherwise }\end{cases}
$$

We will also need a lower bound on $d_{n}$ for our argument. We note that, for example, van der Waerden vdW52 proved a non-trivial lower bound on $d_{n}$, however, for our purposes the following simpler bound is sufficient. Set $\varrho_{n}:=\arccos (1-2 / n)$, and consider a maximal (saturated) set of points $p_{1}, \ldots, p_{m}$ on the unit sphere $S^{2}$, such that their pairwise spherical distances are at least $\varrho_{n}$. By maximality it follows that the spherical circular discs (spherical caps) of radius $\varrho_{n}$ centered at $p_{1}, \ldots, p_{m}$ cover $S^{2}$. As the (spherical) area of such a cap is $4 \pi / n$, we obtain that $m \cdot 4 \pi / n \geq 4 \pi$, that is, $m \geq n$, which implies that $\varrho_{n}:=\arccos (1-2 / n) \leq d_{n}$. As $x \leq \arccos \left(1-x^{2} / 2\right)$ for $0 \leq x \leq 1$, the 
following inequality is immediate

$$
\frac{2}{\sqrt{n}} \leq d_{n}^{*} \leq \delta_{n}^{*}
$$

For $0 \leq \alpha \leq \pi / 2$ and $n \geq 3$ we introduce $f(w, \alpha)=4 \pi \sin w-2 F(w, \alpha)$ and

$$
G(w, n)=4 \pi \sin w+\sum_{i=2}^{n} f\left(w, \delta_{2 i}^{*}\right)
$$

Lemma 3.5. For a fixed $n \geq 3$, the function $G(w, n)$ is continuous and monotonically increasing in $w$ in the interval $\left[0, \delta_{2 n}^{*} / 3\right]$. Furthermore, $G(0, n)=0$ and $G\left(\delta_{2 n}^{*} / 3, n\right) \geq 4 \pi$.

Proof. The continuity of $G$ and that $G(0, n)=0$ are obvious. First we show that the function $f(w, \alpha)$ is monotonically increasing in $w$ for $0 \leq w \leq \alpha / 3$. This clearly implies that $G(w, n)$ is also monotonically increasing in the interval stated in the lemma. As $n \geq 3$, we may and do assume that $w \leq \delta_{6}^{*} / 3=\pi / 6$.

Note that $f(w, \alpha)$ is the area of a zone of half-width $w$ minus the area of its intersection with a second zone of half-width $w$ whose central great circle makes an angle $\alpha$ with the central great circle of the first zone. With the same notations as in the proof of Lemma 3.3 . it is clear that for sufficiently small $\Delta w>0$, the quantity $f(w+\Delta w, \alpha)-f(w, \alpha)$ is (roughly) proportional to $2 l\left(c_{1}\right)-4 l\left(c_{1}^{\prime}\right)-4 l\left(c_{2}^{\prime}\right)=2\left(l\left(c_{1}\right)-4 l\left(c_{1}^{\prime}\right)\right)$. Notice that, for a fixed $w \in[0, \pi / 4]$, the function $l\left(c_{1}^{\prime}\right)=l(w, \alpha)$ is monotonically decreasing in $\alpha$ for $\alpha \in[2 w, \pi / 2]$. Thus, using $3 w \leq \alpha$,

$$
\begin{aligned}
l\left(c_{1}\right)-4 l\left(c_{1}^{\prime}\right) & \geq l\left(c_{1}\right)-4 l(w, 3 w)= \\
& =4 \cos w\left(\frac{\pi}{2}-\arcsin \left(\frac{1-\cos (3 w)}{\cot w \sin (3 w)}\right)-\arcsin \left(\frac{1+\cos (3 w)}{\cot w \sin (3 w)}\right)\right) .
\end{aligned}
$$

One can check that if $w \in(0, \pi / 6]$, then both arguments in the above arcsin functions take on values in $[0,2 / 3]$. By the monotonicity and convexity of arcsin, we obtain that

$$
\begin{array}{r}
\arcsin \left(\frac{1-\cos (3 w)}{\cot w \sin (3 w)}\right)+\arcsin ( \\
\left(\frac{1+\cos (3 w)}{\cot w \sin (3 w)}\right) \leq \arcsin (2 / 3) \frac{3 \tan w}{\sin (3 w)} \\
\leq \arcsin (2 / 3) \frac{3 \tan (\pi / 6)}{\sin (\pi / 2)}=\frac{2 \sqrt{3}}{3}<\frac{\pi}{2}
\end{array}
$$

which shows the monotonicity of $G(w, n)$.

Finally, we show that $G\left(\delta_{2 n}^{*} / 3, n\right) \geq 4 \pi$. For $n \leq 24$, this statement can be checked by direct calculation, thus we may assume $n \geq 25$. Using the definitions of $G$ and $f$, and Lemma 3.3, we obtain that

$$
G\left(\frac{\delta_{2 n}^{*}}{3}, n\right)=n \cdot 4 \pi \sin \frac{\delta_{2 n}^{*}}{3}-2 \cdot \sum_{i=2}^{n} F\left(\frac{\delta_{2 n}^{*}}{3}, \delta_{2 i}^{*}\right)
$$




$$
\begin{aligned}
& \geq 4 n \pi \sin \frac{\delta_{2 n}^{*}}{3}-2 \sum_{i=2}^{n} F\left(\frac{\delta_{2 n}^{*}}{3}, \delta_{2 n}^{*}\right) \\
& =4 n \pi \sin \frac{\delta_{2 n}^{*}}{3}-2(n-1) F\left(\frac{\delta_{2 n}^{*}}{3}, \delta_{2 n}^{*}\right) \\
& \geq 4 n \pi \sin \frac{\delta_{2 n}^{*}}{3}-2(n-1) F\left(\frac{\delta_{2 n}^{*}}{3}, \frac{2 \delta_{2 n}^{*}}{3}\right) .
\end{aligned}
$$

Note that $\delta_{2 n}^{*}=\delta_{2 n}$ for $n \geq 25$. Elementary trigonometry yields that

$$
F\left(\frac{\alpha}{2}, \alpha\right)=4 \sin \frac{\alpha}{2} \arcsin \left(\tan ^{2} \frac{\alpha}{2}\right)+2 \pi \sin \frac{\alpha}{2}-2 \arccos \left(1-2 \tan ^{2} \frac{\alpha}{2}\right) .
$$

Thus (3.7) is equal to

$$
4 \pi \sin \frac{\delta_{2 n}}{3}+4(n-1)\left(\arccos \left(1-2 \tan ^{2} \frac{\delta_{2 n}}{3}\right)-2 \sin \frac{\delta_{2 n}}{3} \arcsin \left(\tan ^{2} \frac{\delta_{2 n}}{3}\right)\right) .
$$

As $n \geq 25$, we have that $0<\delta_{2 n}<0.75$. Using that $\cos x \geq 1-x^{2} / 2$ for $x \in[0, \pi / 2]$, we obtain that

$$
\arccos \left(1-2 \tan ^{2} \frac{\delta_{2 n}}{3}\right) \geq 2 \tan \frac{\delta_{2 n}}{3} .
$$

Similarly, as for $0<x<0.16$ we have that $x<1.01 \sin x$, we obtain that

$$
2 \sin \frac{\delta_{2 n}}{3} \arcsin \left(\tan ^{2} \frac{\delta_{2 n}}{3}\right)<2.02 \tan ^{3} \frac{\delta_{2 n}}{3}
$$

Finally, using that $x-1.01 x^{3}>x-1.01 \cdot 0.4^{2} \cdot x>0.8 x$ for $0<x<0.4$, we obtain that (3.7) can be estimated from below as follows

$$
G\left(\frac{\delta_{2 n}^{*}}{3}, n\right) \geq 6.4(n-1) \tan \frac{\delta_{2 n}}{3}>2.1(n-1) \delta_{2 n}
$$

By (3.6) we know that $\delta_{2 n}>\sqrt{2} / \sqrt{n}$, and thus the proof of Lemma 3.5 is complete.

Now, we are ready to state our main theorem.

Theorem 3.6. For $n \geq 3$, let $w_{n}^{*}$ denote the unique solution of the equation $G(w, n)=4 \pi$ in the interval $\left[0, \delta_{2 n}^{*} / 3\right]$. Then $\arcsin (1 / n)<w_{n}^{*} \leq w_{n}$.

Proof. Let $Z_{i}\left(w_{n}, C_{i}\right), i=1, \ldots, n$ be zones that form a minimal covering of $S^{2}$ with respect to $w$. For $i \in\{1, \ldots, n\}$, let $p_{i}$ be one of the poles of $C_{i}$ and let $p_{n+i}=-p_{i}$. Then there exist two points $p_{i_{1}}, p_{j_{1}} \in\left\{p_{1}, \ldots, p_{2 n}\right\}$ with $i_{1}<j_{1}$ and $j_{1} \neq n+i_{1}$ (that is, $p_{i_{1}}$ and $p_{j_{1}}$ are poles of two different great circles) such that $d_{s}\left(p_{i_{1}}, p_{j_{1}}\right) \leq d_{2 n}^{*}$. Observe that the area of the part of $Z_{i_{1}}$ that is not covered by any $Z_{k}$ with $i_{1} \neq k$ is at most $f\left(w, \delta_{2 n}^{*}\right)$ by Lemma 3.3, inequality (3.6) and Remark 3.4. Now, remove $Z_{i_{1}}$ from the covering and 
repeat the argument for the remaining zones. Note that in the last step of the process, there is only one zone left $Z_{i_{n}}$, so the area of the part of $Z_{i_{n}}$ not covered by any other zone is $4 \pi \sin w$.

If for $k=1, \ldots, n$ we add the areas of $Z_{i_{k}}$ not covered by any $Z_{i_{l}}$ for $l>k$, then the sum is obviously bounded from above by $G(w, n)$. Since $Z_{1}, \ldots, Z_{n}$ cover $S^{2}$, therefore $G(w, n) \geq 4 \pi$, which shows that $w_{n}^{*} \leq w_{n}$. It is also clear form the argument that $\arcsin (1 / n)<w_{n}^{*}$. This finishes the proof of Theorem 3.6 .

Note that instead of Robinson's bound $\delta_{n}$, one may use the original bound $\tilde{\delta}_{n}$ of L. Fejes Tóth, and prove Theorem 3.6, obtaining a lower bound $\tilde{w}_{n}^{*}$ for $w_{n}$. Clearly, this bound is slightly weaker than $w_{n}^{*}$, that is, $\tilde{w}_{n}^{*} \leq w_{n}^{*} \leq w_{n}$. However, thanks to the explicit formula (3.4), $\tilde{w}_{n}^{*}$ can be computed more easily than $w_{n}^{*}$. The difference between $w_{n}^{*}$ and $\tilde{w}_{n}^{*}$ is shown in Table 3.2 for some specific values of $n$.

We also mention that for certain values of $n$ Robinson's upper bound has been improved, see for example Böröczky and Szabó [BS03] for the cases $n=15,16,17$. These stronger upper bounds, if included in the calculations, would provide only a very small improvement on $w_{n}^{*}$, so we decided to use only the known solutions of the Tammes problem and Robinson's general upper bound.

\begin{tabular}{|c|c|c|c|c|}
\hline$n$ & $\arcsin (1 / n)$ & $\tilde{w}_{n}^{*}$ & $w_{n}^{*}$ & $\pi /(2 n)$ \\
\hline 5 & 0.20135 & 0.22983 & 0.22983 & 0.31415 \\
\hline 6 & 0.16744 & 0.18732 & 0.18732 & 0.26179 \\
\hline 7 & 0.14334 & 0.15824 & 0.15824 & 0.22439 \\
\hline 8 & 0.12532 & 0.13692 & 0.13692 & 0.19634 \\
\hline 9 & 0.11134 & 0.12063 & 0.12067 & 0.17453 \\
\hline 10 & 0.10016 & 0.10782 & 0.10787 & 0.15707 \\
\hline 15 & 0.06671 & 0.07044 & 0.07048 & 0.10471 \\
\hline 20 & 0.05002 & 0.05229 & 0.05232 & 0.07853 \\
\hline 24 & 0.04167 & 0.04335 & 0.04337 & 0.06544 \\
\hline 25 & 0.04001 & 0.04157 & 0.04159 & 0.06283 \\
\hline 50 & 0.02000 & 0.02050 & 0.02051 & 0.03141 \\
\hline 100 & 0.01000 & 0.01016 & 0.01017 & 0.01570 \\
\hline
\end{tabular}

Table 3.2: A few bounds for $w_{n}$ 


\section{Chapter 4}

\section{On the multiplicity of arrangements of congruent zones on the sphere}

\subsection{Introduction}

This chapter of the thesis is based on the paper [BFVZ17] written jointly with A. Bezdek, F. Fodor, and V. Vígh. The topic is essentially the same as in Chapter 3 , where we studied coverings of the sphere by spherical zones. In this part of the dissertation we investigate arrangements of zones from a different point of view. The conjecture of L. Fejes Tóth for finding the minimum width of $n$ congruent zones that can cover the sphere can be considered as a problem minimizing the density of coverings by equal zones. Here we will also try minimize the number of mutually intersecting zones. If a point of the sphere belongs exactly $k$ zones, then we say that its multiplicity (in this arrangement) is $k$. Our aim is to minimize the maximum multiplicity of points in an arrangement.

Our motivation comes, in part, from the classical paper of Erdős and Rogers [ER61, where they investigated the multiplicity of coverings of $\mathbb{R}^{d}$ and $S^{d}$ by convex bodies. They proved, using a probabilistic argument, that $\mathbb{R}^{d}(d \geq 3)$ can be covered by translates of a given convex body such that the density of the covering is less than $d \log d+d \log \log d+4 d$ and no point of $\mathbb{R}^{d}$ belongs to more than $e(d \log d+d \log \log d+4 d)$ translates. Later, Füredi and Kang [FK08] gave a different proof of the result of Erdôs and Rogers using John ellipsoids and the Lovász Local Lemma. Böröczky and Wintsche [BW03] showed that for $d \geq 3$ and $0<\varphi<\pi / 2, S^{d}$ can be covered by spherical caps of radius $\varphi$ such that the multiplicity of the covering is at most $400 d \ln d$.

Our aim is to minimize, or at least control, both the density (the total surface area of zones divided by the surface area of the sphere) and the multiplicity. Our method is 
also probabilistic.

Recall from the previous chapter that a plank in the Euclidean $d$-space $\mathbb{R}^{d}$ is a closed region bounded by two parallel hyperplanes. The width of a plank is the distance between its bounding hyperplanes. A (spherical) zone is the intersection of an origin-symmetric Euclidean plank with $S^{d-1}$. The spherical half-width of the zone is $\arcsin (w / 2)$, where $w$ is the width of the plank.

L. Fejes Tóth asked in $\mid$ FT73 the exact value $w(3, n)$ of the width of $n$ congruent zones that can cover $S^{2}$. He conjectured that in the optimal configuration the central great circles of the zones all go through an antipodal pair of points and they are distributed equally. His conjecture (and its generalization to $d$-dimension) was recently proved by Jiang and Polyanskii JP17|as we have mentioned in the previous chapter. It turns out that the optimal configuration is just as conjectured by L. Fejes Tóth, and thus $w(d, n)=\pi / n$.

Here, we examine arrangements of congruent zones on $S^{d-1}$ from the point of view of multiplicity. The multiplicity of an arrangement is the maximal number of zones with nonempty intersection. We seek to minimize the multiplicity for given $d$ and $n$ as a function of the common width of the zones. It is clear that for $n \geq d$, the multiplicity of any arrangement with $n$ congruent zones is at least $d$ and at most $n$. Notice that in the Fejes Tóth configuration the multiplicity is exactly $n$, that is, maximal.

We start with a discussion regarding lower bounds on the multiplicity. If $d=3$ and $n \geq 3$, then the multiplicity of any covering of $S^{2}$ by $n$ congruent zones is at least 3 . Our first result is a very slight strengthening of this simple fact for the case when $n \geq 4$.

Theorem 4.1. Let $n \geq 1$ be an integer, and let $S^{2}$ be covered by the union of $n$ congruent zones. If each point of $S^{2}$ belongs to the interior of at most two zones, then $n \leq 3$. Moreover, if $n=3$, then the three congruent zones are pairwise orthogonal.

The first statement of theorem can be rephrased as follows: If $n \geq 4$ congruent zones cover $S^{2}$, then there is a point that belongs to the interior of at least three zones. Note that Theorem 4.1 does not imply that the multiplicity of a covering of $S^{2}$ with $n \geq 4$ congruent zones would have to be larger than 3 . In fact, one can cover $S^{2}$ with 4 zones such that the multiplicity is 3 . For this, consider three zones whose central great circles pass through a pair of antipodal points (North and South Poles) and are distributed evenly. Let the central great circle of the fourth zone be the Equator. The common width can be chosen in such a way that there is no point contained in more than three zones. Also, one can arrange five zones such that the multiplicity is still 3. We start with the previously given four zones, and take another copy of the zone whose central great 
circle is the Equator. Now slightly tilt these two zones. It is not difficult to see that the multiplicity of the resulting configuration is 3 .

We further note, see Remark 4.6, that the statement of Theorem 4.1 can probably be extended to all $d \geq 3$. In particular, it certainly holds for $3 \leq d \leq 100$.

Now, we turn to the question of finding upper bounds on the multiplicity of arrangements of zones on $S^{d-1}$. This is a more technical result that needs some notations, some of which will only be explained later. Let $\alpha: \mathbb{N} \rightarrow(0,1]$ be a positive real function with $\lim _{n \rightarrow \infty} \alpha(n)=0$. For a positive integer $d \geq 3$, let $m_{d}=\sqrt{2 \pi d}+1$. Let $k: \mathbb{N} \rightarrow \mathbb{N}$ be a function that satisfies the limit condition

$$
\limsup _{n \rightarrow \infty} \alpha(n)^{-(d-1)}\left(\frac{e C_{d}^{*} n \alpha(n)}{k(n)}\right)^{k(n)}=\beta<1,
$$

where

$$
C_{d}^{*}=\frac{4\left(m_{d}+1\right)(d-1) \kappa_{d-1}}{d \kappa_{d}}
$$

The following theorem is essentially the main result of this chapter. Note, however, that it concerns not only coverings of the sphere by congruent zones but also arrangements in general that may not cover $S^{d-1}$.

Theorem 4.2. For each positive integer $d \geq 3$, and any real function $\alpha(n)$ described above, for sufficiently large $n$, there exists an arrangement of $n$ zones of spherical halfwidth $m_{d} \alpha(n)$ on $S^{d-1}$ such that no point of $S^{d-1}$ belongs to more than $k(n)$ zones.

The following statement provides an upper bound on the multiplicity of coverings of the $d$-dimensional unit sphere by $n$ congruent zones.

Theorem 4.3. For each positive integer $d \geq 3$, there exists a positive constant $A_{d}$ such that for sufficiently large $n$, there is a covering of $S^{d-1}$ by $n$ zones of half-width $m_{d} \frac{\ln n}{n}$ such that no point of $S^{d-1}$ belongs to more than $A_{d} \ln n$ zones.

Below we list some interesting special cases of Theorem 4.3 according to the size of the function $\alpha(n)$.

Corollary 4.4. With the same hypotheses as in Theorem 4.2, the following statements hold.

i) If $\alpha(n)=n^{-(1+\delta)}$ for some $\delta>0$, then $k(n)=$ const.. Moreover, if $\delta>d-1$, then $k(n)=d$.

ii) If $\alpha(n)=\frac{1}{n}$, then $k(n)=B_{d} \frac{\ln n}{\ln \ln n}$ for some suitable constant $B_{d}$. 
We note that Theorem 4.3 and an implicit version of Theorem 4.2 were proved by Frankl, Nagy and Naszódi for the case $d=3$, see [FNN16, Theorem 1.5 and Theorem 1.6] and also the proof of Theorem 1.5 therein. They provided two independent proofs, one of which is a probabilistic argument and the other one uses the concept of VC-dimension. We further add that the weaker upper bound of $O(\sqrt{n})$ on the minimum multiplicity of coverings of $S^{2}$ was posed as an exercise in the 2015 Miklós Schweitzer Mathematical Competition KN16 by A. Bezdek, F. Fodor, V. Vígh and T. Zarnócz (cf. Exercise 7).

Our proofs of Theorems 4.2 and 4.3 are based on the probabilistic argument of Frankl, Nagy and Naszódi [FNN16], which we modified in such a way that it works in all dimensions. In the course of the proof we also give an upper estimate for the constant $A_{d}$ whose order of magnitude is $O(d)$.

Obviously, there is a big gap between the lower and upper bounds for the multiplicity of coverings of $S^{d-1}$ by congruent zones. At this time, it is an open problem if the minimum multiplicity of coverings of $S^{d-1}$ by $n$ congruent zones is bounded or not, and it also remains unknown whether the multiplicity is monotonic in $n$, see the corresponding conjectures of Frankl, Nagy and Naszódi on $S^{2}$ in [FNN16, Conjectures 4.2 and 4.4].

\subsection{Proofs}

\subsubsection{Proof of Theorem 4.1}

Assume that $n \geq 3$ and $S^{2}$ is covered by $n$ congruent zones such that no point of $S^{2}$ belongs to the interior of more than two zones. Then the $n$ central great circles of the zones divide $S^{2}$ into convex spherical polygons. As no three such great circles can pass through a point of $S^{2}$, every such polygon has at least three sides.

In contrast to the Euclidean plane, the incircle of every convex spherical polygon is uniquely determined. The inradius of each such polygon is less than or equal to the half-width of the zones.

We will use the following lemma.

Lemma 4.5. Every convex spherical polygon with $k>3$ sides and inradius $r$ contains a point $P$ whose distance from at least three sides is less than $r$.

Proof. Denote the incircle by $C$ and denote its centre by $O$.

Case 1. There are at least three sides tangent to the incircle $C$.

Among the tangent sides there are two, say $e$ and $f$, which are not adjacent on the boundary of $C$. The extensions of $e$ and $f$ form a spherical 2-gon. Start moving the centre 
$O$ along the diagonal of this 2-gon towards its closest endpoint. Then the distance of $O$ from the extended sides $e$ and $f$ continuously decrease and $O$ eventually gets arbitrarily close to an additional side. When this happens $O$ is closer than $r$ to at least three sides. Case 2. There are exactly two sides tangent to the incircle $C$.

Let $e$ and $f$ be the only two sides tangent to the incircle $C$. Consider again the 2-gon whose sides are the extensions of $e$ and $f$. Notice that $C$ is also the incircle of this 2gon. Thus, moving $O$ along the diagonal towards either of the two endpoints continuously decreases the distance of $O$ from the extended sides $e$ and $f$. At least one of the directions will take $O$ arbitrarily close to an additional side. When this happens $O$ is, again, closer than $r$ to at least three sides.

Lemma 4.5yields immediately that each spherical polygon determined by the $n$ central great circles of the zones is a spherical triangle. The vertices and sides of these triangular domains form a planar graph $G$ on $S^{2}$. The number $v$ of vertices is $2\left(\begin{array}{l}n \\ 2\end{array}\right)$, and the number of edges is $2 n(n-1)$. By Euler's formula, the number $f$ of faces (the number of spherical triangles) is

$$
f=e+2-v=n^{2}-n+2 .
$$

Furthermore, the degree of each vertex is four, thus $4 v=3 f$, which yields that

$$
n^{2}-n-6=0 \text {. }
$$

The only positive root of the above quadratic equation is $n=3$.

Let $n=3$, and assume that the central great circles of two zones intersect in the North and South poles of $S^{2}$. The part of $S^{2}$ not covered by these two zones is the union of two or four spherical 2-gons bounded by small circular arcs that are parts of the boundaries of the zones. If the uncovered part consists of only two such 2-gons, then there must be a point of $S^{2}$ which belongs to the interior of all three zones. As the vertices of the uncovered 2-gons that are on the same hemisphere (say the Northern one) must be on one of the bounding small circles of the third zone, they must be coplanar. This is only satisfied when the first two zones are perpendicular. This finishes the proof of Theorem 4.1 .

Remark 4.6. Consider now $n$ congruent zones on $S^{d-1}$ such that no point belongs to the interior of more than $d-1$ zones. Then the central great spheres of the zones divide $S^{d-1}$ into convex spherical polytopes similar to the 3 -dimensional case. We note that the argument of Lemma 4.5 can be generalized to arbitrary $d$, only one has to consider $d-1$ cases instead of two. Thus, the central great spheres of the zones divide $S^{d-1}$ into spherical simplices. 
Now, a similar combinatorial analysis can be carried out, with the help of the EulerPoincaré formula, as in $S^{2}$. Let $f_{i, d}(n)$ denote the number of $i$-dimensional faces determined by the central great spheres of the $n$ zones for $d \geq 3$ and $n \geq d-1$. We use the conventions: $f_{-1, d}(n)=1$ and $f_{d, d}(n)=1$. As we have seen in the proof of Lemma 4.5 . $f_{0,3}=2\left(\begin{array}{l}n \\ 2\end{array}\right), f_{1,3}(n)=2 n(n-1)$, and $f_{2,3}=n^{2}-n+2$.

Then we have the following recursions for $f_{i, d}(n)$ when $d \geq 4$ :

$$
\begin{aligned}
f_{0, d}(n) & =2\left(\begin{array}{c}
n \\
d-1 \\
n
\end{array}\right), \\
f_{i, d}(n) & =\frac{n}{d-i-1} f_{i, d-1}(n-1) \quad(1 \leq i \leq d-2), \\
f_{d-1, d}(n) & =\frac{2}{d} f_{d-2, d}(n) .
\end{aligned}
$$

As the $n$ central great spheres are in general position, a vertex is incident with exactly $d-1$ of them, which explains the formula for $f_{0, d}(n)$. Since the cells are simplices, counting its facets one gets the identity $2 f_{d-2, d}(n)=d f_{d-1, d}(n)$. Finally, if $1 \leq i \leq d-2$, then consider a fixed central great sphere. The other central great spheres intersect the chosen one in $n-1$ great spheres (of one less dimension) that are in general position. Taking into account that we have $n$ great spheres and that an $i$-dimensional face is incident with exactly $d-i-1$ great spheres, one gets the second formula above.

Now, for a fixed $d$, using the Euler-Poincaré formula, $\sum_{i=-1}^{d}(-1)^{d+1} f_{i, d}(n)=0$ this holds as we have a triangulation of $S^{d-1}$ into simplices one can obtain a polynomial equation $p(d, n)=0$ of degree at most $d-1$ in $n$. When $n=d$, then $n$ pairwise orthogonal congruent zones satisfy all conditions, thus, $n=d$ is always a root of $p(d, n)$. In particular, for $4 \leq d \leq 6$, the reduced forms of $p(d, n)$ in which the coefficient of $n^{d-1}$ is 1 are the following

$$
\begin{aligned}
& p(4, n)=(n-4)(n+1) n, \\
& p(5, n)=(n-5)\left(n^{3}-n^{2}-2 n-8\right), \\
& p(6, n)=(n-6)(n-2)(n-1)^{2} n .
\end{aligned}
$$

Thus, if $d=4$ or 6 , then $n=d$ is the largest root that satisfies our conditions. In the case $d=5$ one can check that $p(5, d)$ has two complex roots and two real roots, one real root is 5 and the other one is smaller than 5 .

We can now formulate the following conjecture.

Conjecture 4.7. Let $d \geq 3$ and $n \geq 1$ be integers, and let $S^{d-1}$ be covered by the union of $n$ congruent zones. If each point of $S^{d-1}$ belongs to the interior of at most $d-1$ zones, then $n \leq d-1$. Moreover, if $n=d$, then the $d$ congruent zones are pairwise orthogonal 
By Theorem 4.1 and the above argument we have proved the first statement of Conjecture 4.7 for $3 \leq d \leq 6$. If $n=d$, then the orthogonality of the zones can be proved essentially the same way as in the proof of Theorem 4.1. Furthermore, we have computed the roots of $p(d, n)$ for $7 \leq d \leq 100$ by computer (numerically) and observed than in each case the largest real root is $n=d$, which supports our conjecture.

Finally we note that computer calculations suggest that in the case when $d \geq 6$ is even,

$$
p(d, n)=(n-d)(n-d+5) \prod_{i=0}^{d-4}(n-i) .
$$

\subsubsection{Proof of Theorem 4.2}

For two points $P, Q \in S^{d-1}$, their spherical distance is the length of the shorter unitradius circular arc on $S^{d-1}$ that connects them. We denote the spherical distance by $d_{S}(P, Q)$.

Let $0<\omega \leq \pi / 2$. We say that the points $P_{1}, \ldots, P_{m} \in S^{d-1}$ form a saturated set for $\omega$ if the spherical distances $d_{S}\left(P_{i}, P_{j}\right) \geq \omega$ for all $i \neq j$ and no more points can be added such that this property holds. Investigating the dependence of $m$ on $d$ and $\omega$ is a classical topic in the theory of packing and covering; for a detailed overview of known results in this direction see, for example, the survey paper by G. Fejes Tóth and Kuperberg |FTK93.

It is clear that $m$ is of the same order of magnitude as $\omega^{-(d-1)}$. In the next lemma, we prove a somewhat more precise statement. Although the content of the lemma is well-known, we give a proof because we need inequalities for $m$ with exact constants in subsequent arguments, and also for the sake of completeness. Let $\kappa_{d}$ denote the volume of the $d$-dimensional unit ball $B^{d}$.

Lemma 4.8. Let $0<\varepsilon<1$. Then there exists $0<\omega_{0} \leq \pi / 2$ depending on $\varepsilon$ with the following property. Let $0<\omega<\omega_{0}$, and let $P_{1}, \ldots, P_{m}$ be a saturated point set for $\omega$. Then

$$
(1+\varepsilon)^{-1} \frac{d \kappa_{d}}{\kappa_{d-1}} \omega^{-(d-1)} \leq m \leq(1+\varepsilon) \frac{8^{\frac{d-1}{2}} d \kappa_{d}}{\kappa_{d-1}} \omega^{-(d-1)} .
$$

Proof. The following formula is known for the surface area $S(t)$ of a cap of height $t$ of $S^{d-1}$, cf. [BFH13, formula (3.4) on p. 796],

$$
\lim _{t \rightarrow 0+} S(t) t^{-\frac{d-1}{2}}=2^{\frac{d-1}{2}} \kappa_{d-1} .
$$

Therefore, there exists $0<t_{0}=t_{0}(\varepsilon)$ such that for all $0<t<t_{0}$ it holds that 


$$
(1+\varepsilon)^{-1} 2^{\frac{d-1}{2}} \kappa_{d-1} \leq S(t) t^{-\frac{d-1}{2}} \leq(1+\varepsilon) 2^{\frac{d-1}{2}} \kappa_{d-1} .
$$

Furthermore, let $0<\omega_{0}=\omega_{0}(\varepsilon)$ be such that $t_{0}=1-\cos \omega_{0}$.

The spherical caps of (spherical) radius $\omega / 2$ centred at $P_{1}, \ldots, P_{m}$ form a packing on $S^{d-1}$, and the spherical caps of radius $\omega$ form a covering of $S^{d-1}$. In view of the above inequalities for the surface area of caps, we obtain that for $0<\omega<\omega_{0}$ it holds that

$$
m(1+\varepsilon)^{-1} 2^{\frac{d-1}{2}} \kappa_{d-1}\left(1-\cos \frac{\omega}{2}\right)^{\frac{d-1}{2}} \leq d \kappa_{d} \leq m(1+\varepsilon) 2^{\frac{d-1}{2}} \kappa_{d-1}(1-\cos \omega)^{\frac{d-1}{2}} .
$$

By simple rearrangement we get that

$$
(1+\varepsilon)^{-1} \frac{d \kappa_{d}}{2^{\frac{d-1}{2}} \kappa_{d-1}(1-\cos \omega)^{\frac{d-1}{2}}} \leq m \leq(1+\varepsilon) \frac{d \kappa_{d}}{2^{\frac{d-1}{2}} \kappa_{d-1}\left(1-\cos \frac{\omega}{2}\right)^{\frac{d-1}{2}}} .
$$

Now, we use that for $0<x<1$, it holds that $x^{2} / 4<1-\cos x<x^{2} / 2$, which follow simply from the Taylor series of $\cos x$, and obtain the desired inequalities

$$
(1+\varepsilon)^{-1} \frac{d \kappa_{d}}{\kappa_{d-1}} \omega^{-(d-1)} \leq m \leq(1+\varepsilon) \frac{8^{\frac{d-1}{2}} d \kappa_{d}}{\kappa_{d-1}} \omega^{-(d-1)} .
$$

We denote a spherical zone of (spherical) half-width $t$ by $\Pi(t)$. Since, for small $t$, it holds that

$$
2(d-1) \kappa_{d-1} \sin t<S(\Pi(t))<2(d-1) \kappa_{d-1} t
$$

it follows that

$$
\lim _{t \rightarrow 0^{+}} S(\Pi(t)) \cdot t^{-1}=2(d-1) \kappa_{d-1} .
$$

Let $\varepsilon>0$. Then there exists $t_{1}=t_{1}(\varepsilon)>0$ such that for $0<t<t_{1}$ the following holds

$$
(1+\varepsilon)^{-1} 2(d-1) \kappa_{d-1} t \leq S(\Pi(t)) \leq(1+\varepsilon) 2(d-1) \kappa_{d-1} t
$$

Let $\alpha(n)$ be a given positive function with $\lim _{n \rightarrow \infty} \alpha(n)=0$. From now on, we fix $\varepsilon=1$, set $m_{d}=\sqrt{2 \pi d}+1$, and assume $n$ to be sufficiently large.

Let $Q_{1}, \ldots, Q_{m}$ be a saturated set of points on $S^{d-1}$ such that $d_{S}\left(Q_{i}, Q_{j}\right) \geq \alpha(n) / 2$ for any $i \neq j$. It follows from Lemma 1 that

$$
\begin{aligned}
m & \leq 2 \frac{8^{\frac{d-1}{2}} d \kappa_{d}}{\kappa_{d-1}}(\alpha(n) / 2)^{-(d-1)} \\
& =2 \frac{2^{\frac{d-1}{2}} d \kappa_{d}}{\kappa_{d-1}} \alpha(n)^{-(d-1)}
\end{aligned}
$$




$$
=c_{d} \alpha(n)^{-(d-1)}
$$

Consider $n$ independent random points from $S^{d-1}$ chosen according to the uniform probability distribution and consider the corresponding spherical zones $\Pi_{1}, \ldots, \Pi_{n}$ of (spherical) half-width $m_{d} \alpha(n)$ whose poles are these points. Furthermore, let $\Pi_{i}^{-}, \Pi_{i}^{+}$be the corresponding planks of half-width $\left(m_{d}-1\right) \alpha(n)$ and $\left(m_{d}+1\right) \alpha(n)$, respectively.

Now, we are going to estimate the probability of the event that there exists a point $p$ on $S^{d-1}$ which belongs to at least $k=k(n)$ zones. The probability that a point $p \in S^{d-1}$ belongs to a spherical plank $\Pi_{i}^{+}$can be estimated from above as follows.

$$
\mathbb{P}\left(p \in \Pi_{i}^{+}\right) \leq \frac{4\left(m_{d}+1\right)(d-1) \kappa_{d-1}}{d \kappa_{d}} \alpha(n)=C_{d}^{*} \alpha(n) .
$$

Note that $C_{d}^{*}=O(d)$ as $d \rightarrow \infty$.

Then

$$
\begin{aligned}
& \mathbb{P}\left(\exists p \in \Pi_{i_{1}} \cap \cdots \cap \Pi_{i_{k}}: \text { for some } 1 \leq i_{1}<\ldots<i_{k} \leq n\right) \\
\leq & \mathbb{P}\left(\exists Q_{j} \in \Pi_{i_{1}}^{+} \cap \cdots \cap \Pi_{i_{k}}^{+}: \text {for some } 1 \leq i_{1}<\ldots<i_{k} \leq n\right) \\
\leq & m \cdot \mathbb{P}\left(Q_{1} \in \Pi_{i_{1}}^{+} \cap \cdots \cap \Pi_{i_{k}}^{+}: \text {for some } 1 \leq i_{1}<\ldots<i_{k} \leq n\right) \\
\leq & m \cdot\left(\begin{array}{c}
n \\
k(n)
\end{array}\right)\left(C_{d}^{*} \alpha(n)\right)^{k(n)} \\
\leq & c_{d} \alpha(n)^{-(d-1)}\left(\begin{array}{c}
n \\
k(n)
\end{array}\right)\left(C_{d}^{*} \alpha(n)\right)^{k(n)}
\end{aligned}
$$

An application of the Stirling-formula (cf. Page 10 of $[\overline{\text { FNN16 }}]$ ) yields that

$$
\left(\begin{array}{l}
n \\
k
\end{array}\right) \leq C \frac{n^{n}}{k^{k}(n-k)^{n-k}}
$$

for some suitable constant $C>0$.

Then applying (4.2) we get that

$$
\begin{aligned}
& c_{d} \alpha(n)^{-(d-1)}\left(\begin{array}{c}
n \\
k(n)
\end{array}\right)\left(C_{d}^{*} \alpha(n)\right)^{k(n)} \\
\leq & c_{d} \alpha(n)^{-(d-1)} \cdot C \frac{n^{n}(n-k(n))^{k(n)}}{(k(n))^{k(n)-n}}\left(C_{d}^{*} \alpha(n)\right)^{k(n)} \\
\leq & \tilde{c_{d}} \alpha(n)^{k(n)-d+1}\left(\frac{n}{k(n)}\right)^{k(n)}\left(e \cdot C_{d}^{*}\right)^{k(n)} \\
= & \tilde{c}_{d} \alpha(n)^{-(d-1)}\left(\frac{e C_{d}^{*} n \alpha(n)}{k(n)}\right)^{k(n)} .
\end{aligned}
$$


By (4.1) we obtain

$$
\limsup _{n \rightarrow \infty} \mathbb{P}\left(\exists p \in \Pi_{i_{1}} \cap \cdots \cap \Pi_{i_{k}}: \text { for some } 1 \leq i_{1}<\ldots<i_{k} \leq n\right)<1,
$$

therefore the probability of the event that no point of $S^{d-1}$ belongs to at least $k(n)$ zones is positive for sufficiently large $n$. This finishes the proof of Theorem 4.2 .

\subsubsection{Proof of Theorem 4.3}

Let $\alpha(n)=\frac{\ln n}{n}$, and let $k(n)=A_{d} \ln n$, where $A_{d}$ be a suitable positive constant that satisfies the following equation

$$
\left(\frac{C_{d}^{*}}{x}\right)^{x}=e^{-d-x}
$$

Then

$$
4.1)=\lim _{n \rightarrow \infty} \tilde{c_{d}} \frac{n^{d-1}}{(\ln n)^{d-1}} \cdot n^{A_{d}}\left(\frac{C_{d}^{*}}{A_{d}}\right)^{A_{d} \ln n}=0 .
$$

Furthermore, in this case the probability that an arbitrary fixed point $p$ of $S^{d-1}$ is in $\Pi_{i}^{-}($for a fixed $i)$ is

$$
\mathbb{P}\left(p \in \Pi_{i}^{-}\right) \geq 2^{-1} \cdot \frac{2(d-1) \kappa_{d-1}}{d \kappa_{d}} \cdot\left(m_{d}-1\right) \alpha(n) .
$$

Using the inequality $\frac{\kappa_{d-1}}{d \kappa_{d}}>\frac{1}{\sqrt{2 \pi d}}(\mathrm{cf}$. Lemma 1 in $\mid$ BGW82|), we obtain that

$$
\mathbb{P}\left(p \in \Pi_{i}^{-}\right) \geq \frac{\left(m_{d}-1\right)(d-1)}{\sqrt{2 \pi d}} \cdot \frac{\ln n}{n}=(d-1) \frac{\ln n}{n}
$$

Thus, the probability that $\cup_{1}^{n} \Pi_{i}$ does not cover $S^{d-1}$ satisfies

$$
\begin{aligned}
\mathbb{P}\left(S^{d-1} \not \cup_{1}^{n} \Pi_{i}\right) & \leq \mathbb{P}\left(\exists Q_{j} \notin \cup_{1}^{n} \Pi_{i}^{-}\right) \\
& \leq m \cdot \mathbb{P}\left(Q_{1} \notin \cup_{1}^{n} \Pi_{i}^{-}\right) \\
& \leq c_{d}\left(\frac{n}{\ln n}\right)^{d-1} \cdot\left(1-(d-1) \frac{\ln n}{n}\right)^{n} \\
& \leq 2 c_{d}\left(\frac{1}{\ln n}\right)^{d-1}
\end{aligned}
$$

for a sufficiently large $n$. Therefore

$$
\lim _{n \rightarrow \infty} \mathbb{P}\left(S^{d-1} \not \subset \cup_{1}^{n} \Pi_{i}\right)=0 .
$$

Thus, taking into account (4.4) and (4.5), the probability of the event that all $S^{d-1}$ is covered by the zones and no point of $S^{d-1}$ belongs to more than $A_{d} \ln n$ zones is positive for sufficiently large $n$. This finishes the proof of Theorem 4.3 . 
We note that $A_{d}=O(d)$ as $d \rightarrow \infty$. Clearly, $A_{d}$ can be lowered slightly by taking into account all the factors of (4.4).

We further note that one can obtain the result of Theorem 4.3 with the help of Theorem 1.6 of [FNN16] using the VC-dimension of hypergraphs; for more details we refer to the discussion in [FNN16] after Theorem 1.6. However, as this alternate proof is less geometric in nature, we decided to describe the more direct probabilistic proof of Theorem 4.3. We leave the proof of Theorem 4.3 that uses the VC-dimension to the interested reader. Furthermore, the direct probabilistic argument provides an explicit estimate of the involved constant $A_{d}$, as well.

\subsubsection{Proof of Corollary 1}

Let $\alpha(n)=\frac{1}{n^{1+\delta}}$ for some $\delta>0$. If $k=k(n)>(d-1) / \delta+d-1$, then

$$
\begin{aligned}
\limsup _{n \rightarrow \infty} \alpha(n)^{-(d-1)}\left(\frac{e C_{d}^{*} n \alpha(n)}{k(n)}\right)^{k(n)} & =\lim _{n \rightarrow \infty} n^{(1+\delta)(d-1)}\left(\frac{e C_{d}^{*} n^{-\delta}}{k}\right)^{k} \\
& =\lim _{n \rightarrow \infty} n^{(1+\delta)(d-1)-\delta k}=0 .
\end{aligned}
$$

This means that in this case, for sufficiently large $n$, we can guarantee that one can arrange $n$ zones of half-width $m_{d} \alpha(n)$ on $S^{d-1}$ such that no point belongs to more than $k=$ const. zones, and the value of $k$ only depends on $d$ and $\delta$. Moreover, if $\delta>d-1$, then $k=d$ suffices. Of course, in this case the zones cannot cover $S^{d-1}$. This proves i) of Corollary 1.

Now, let $\alpha(n)=\frac{1}{n}$, and let $k(n)=B_{d} \frac{\ln n}{\ln \ln n}$, where $B_{d}>\max \left\{e C_{d}^{*}, d-1\right\}$ is a positive constant. Then

$$
\begin{aligned}
& \limsup _{n \rightarrow \infty} \alpha(n)^{-(d-1)}\left(\frac{e C_{d}^{*} n \alpha(n)}{k(n)}\right)^{k(n)}=\lim _{n \rightarrow \infty} n^{d-1}\left(\frac{e C_{d}^{*} \ln \ln n}{B_{d} \ln n}\right)^{B_{d} \frac{\ln n}{\ln \ln n}} \\
& \leq \lim _{n \rightarrow \infty}\left(\frac{n^{\frac{(d-1) \ln \ln n}{B_{d} \ln n}} \ln \ln n}{\ln n}\right)^{B_{d} \frac{\ln n}{\ln \ln n}}=0 \text {, }
\end{aligned}
$$

as

$$
\begin{aligned}
& \lim _{n \rightarrow \infty} \frac{n^{\frac{(d-1) \ln n}{B_{d} \ln n} \ln \ln n}}{\ln n} \\
= & \lim _{n \rightarrow \infty} \exp \left(\frac{d-1}{B_{d}} \ln \ln n+\ln \ln \ln n-\ln \ln n\right)=0 .
\end{aligned}
$$

This finishes the proof of part ii) of Corollary 1. The above statement is interesting because $\alpha(n)=\frac{1}{n}$ is the smallest order of magnitude for the half-width of the zones for which one can possibly have a covering. 
We note that the $d=3$ special case of part ii) of Corollary 1 was explicitly proved by Frankl, Nagy and Naszódi in |FNN16| (cf. Theorem 4.1) in a slightly different form both by the probabilistic method and using VC-dimension. We also note that the general $d$-dimensional statement of part ii) of Corollary 1 may also be proved from Theorem 1.6 of FNN16]. 


\section{Chapter 5}

\section{On the volume bound in the Dvoretzky-Rogers lemma}

\subsection{Introduction}

This chapter is based on the paper [FNZ18] written jointly with F. Fodor and M. Naszódi.

The topic of this part of the dissertation is slightly different from the previous three which all belong to discrete geometry. The subject of this chapter is more part of the theory of convex bodies. The study of properties of ellipsoids associated with convex bodies is a rich topic in convexity. One of the classical results by John states that each convex body contains a unique ellipsoid of maximal volume. It also has a famous counterpart according to which each convex body is contained in a unique ellipsoid (Loewner's ellipsoid) of minimal volume. Each convex body has an affine image in which the largest volume ellipsoid is the unit ball $B^{d}$. This relationship can be characterized in terms of the contact points of the convex body and the sphere, see the exact statement below, cf. Theorem 5.3. It turns out that in this case one can select a finite set of vectors from the contact points that, with suitable positive weights, form a so-called isotropic vector system, for the exact definition see also below. The term isotropic refers to the property that for an arbitrary vector of space, if one adds the weighted components of this vector parallel to the elements of the isotropic set, then one obtains the original vector. This means that the weighted sum of the orthogonal projections to the lines determined by the isotropic vectors is the identity map. This property has important consequences. One such consequence is that such a vector system contains a subset that is close to an orthonormal basis, and thus, spans a parallelotope of large volume. This is the contents of the Dvoretzky-Rogers lemma, cf. Lemma 5.4 which gives a lower bound for the max- 
imal volume of this parallelotope. In this chapter we look at this volume bound from a different, in fact, probabilistic point of view.

We note that our study of (5.7) is motivated in part by the recent proof $\mid$ Nas16b of a conjecture of Bárány, Katchalski and Pach [BKP84, BKP82, where this bound is heavily relied on. However, in this dissertation we do not elaborate on this.

Given a set of isotropic vectors in Euclidean $d$-space $\mathbb{R}^{d}$ (see definition below), the Dvoretzky-Rogers lemma states that one may select a subset of $d$ "well spread out" vectors. As a consequence, the determinant of these $d$ vectors is at least $\sqrt{d ! / d^{d}}$. This selection is deterministic: we start with an arbitrary element of the set, and then select more vectors one-by-one in a certain greedy manner.

Pivovarov [Piv10, Lemma 3, p. 49], on the other hand, chooses $d$ vectors randomly and then computes the expectation of the square of the resulting determinant. In this note, we extend Pivovarov's result to a wider class of measures, and apply this extension to obtain the improved lower bound of Pelczyński and Szarek, cf. PS91]Proposition 2.1, on the maximum of the volume of parallelotopes spanned by $d$ vectors from the support of the measure. Thus, we give a probabilistic interpretation of the volume bound in the Dvoretzky-Rogers lemma.

We denote the Euclidean scalar product by $\langle\cdot, \cdot\rangle$, the induced norm by $|\cdot|$. Recall that a compact convex set $K \subset \mathbb{R}^{d}$ with non-empty interior a is called a convex body. For more information and background on the properties of convex bodies and the general theory, we refer to the books by Gruber Gru07] and Schneider [Sch14.

Let $\operatorname{Id}_{d}$ be the identity map on $\mathbb{R}^{d}$. For $u, v \in \mathbb{R}^{d}$, let $u \otimes v: \mathbb{R}^{d} \rightarrow \mathbb{R}^{d}$ denote the tensor product of $u$ and $v$, that is, $(u \otimes v)(x)=\langle v, x\rangle u$ for any $x \in \mathbb{R}^{d}$. Note that when $u \in S^{d-1}$ is a unit vector, $u \otimes u$ is the orthogonal projection to the linear subspace spanned by $u$.

For two functions $f(n), g(n)$, we use the notation $f(n) \sim g(n)($ as $n \rightarrow \infty)$ if $\lim _{n \rightarrow \infty} f(n) / g(n)=1$.

An isotropic measure is a probability measure $\mu$ on $\mathbb{R}^{d}$ with the following two properties.

$$
\int_{\mathbb{R}^{d}} x \otimes x \mathrm{~d} \mu(x)=\mathrm{Id}_{d}
$$

and the center of mass of $\mu$ is at the origin, that is,

$$
\int_{\mathbb{R}^{d}} x \mathrm{~d} \mu(x)=0
$$

Pivovarov |Piv10 proved the following statement about the volume of random parallelotopes spanned by $d$ independent, isotropic vectors. 
Lemma 5.1 (Pivovarov |Piv10|, Lemma 3). Let $x_{1}, \ldots, x_{d}$ be independent random vectors distributed according to the isotropic measures $\mu_{1}, \ldots, \mu_{d}$ in $\mathbb{R}^{d}$. Assume that $x_{1}, \ldots, x_{d}$ are linearly independent with probability 1 . Then

$$
\mathbb{E}\left(\left[\operatorname{det}\left(x_{1}, \ldots, x_{d}\right)\right]^{2}\right)=d !
$$

We note that Lutwak, Yang and Zhang in [LYZ04, §2] established similar results for the case of discrete isotropic measures, which could also be used to prove the volumetric bounds in Theorem 5.5, see, for example, [LYZ04, formula (2.5) on page 167].

We extend Lemma 5.1 to a more general class of measures in the following way.

Lemma 5.2. Let $x_{1}, \ldots, x_{d}$ be independent random vectors distributed according to the probability measures $\mu_{1}, \ldots, \mu_{d}$ in $\mathbb{R}^{d}$ satisfying (5.1). Assume that $\mu_{i}(\{0\})=0$ for $i=1, \ldots$, d. Then 5.3 holds.

We provide a simple and direct proof of Lemma 5.2 in Section 5.2 .

Lemmas 5.1 and 5.2 yield the value of the second moment of the volume of random parallelotopes with isotropic generating vectors. On the other hand, Milman and Pajor [MP, §3.7] gave a lower bound for the $p$-th moment (with $0<p<2$ ) of this volume in the case when the generating vectors are selected according to the uniform distribution from an isotropic and origin-symmetric convex body; for more general results, cf. BGVV14, §3.5.1]. All of the previously mentioned results hold in expectation.

As a different approach, we mention Pivovarov's work [Piv10], where lower bounds on the volume of a random parallelotope are shown to hold with high probability under the assumption that the measures are log-concave.

The literature on properties of random parallelotopes and random polytopes in general is very rich and extensive. An overview of this topic would be beyond the scope of this dissertation. For more information, we rather refer to the book by Schneider and Weil SW08, the survey by Schneider [Sch], and the references therein.

In this chapter, our primary, geometric motivation in studying isotropic measures is the following celebrated theorem of John [Joh48], which we state in the form given by Ball Bal92 (see also Bal97]).

Theorem 5.3. Let $K$ be a convex body in $\mathbb{R}^{d}$. Then there exists a unique ellipsoid of maximal volume contained in $K$. Moreover, this maximal volume ellipsoid is the $d$ dimensional unit ball $B^{d}$ if and only if there exist vectors $u_{1}, \ldots, u_{m} \in \mathrm{bd} K \cap S^{d-1}$ and (positive) real numbers $c_{1}, \ldots, c_{m}>0$ such that

$$
\sum_{i=1}^{m} c_{i} u_{i} \otimes u_{i}=\operatorname{Id}_{d},
$$


and

$$
\sum_{i=1}^{m} c_{i} u_{i}=0 .
$$

Note that taking the trace in (5.4) yields $\sum_{i=1}^{m} c_{i}=d$. Thus, the Borel measure $\mu_{K}$ on $\sqrt{d} S^{d-1}$ with $\operatorname{supp} \mu_{K}=\left\{\sqrt{d} u_{1}, \ldots, \sqrt{d} u_{m}\right\}$ and $\mu_{K}\left(\left\{\sqrt{d} u_{i}\right\}\right)=c_{i} / d(i=1, \ldots, m)$ is a discrete isotropic measure.

If a finite system of unit vectors $u_{1}, \ldots, u_{m}$ in $\mathbb{R}^{d}$, together with a set of positive weights $c_{1}, \ldots, c_{m}$ satisfies (5.4) and (5.5), then we say that it forms a John decomposition of the identity. For each convex body $K$, there exists an affine image $K^{\prime}$ of $K$ for which the maximal volume ellipsoid contained in $K^{\prime}$ is $B^{d}$, and $K^{\prime}$ is unique up to orthogonal transformations of $\mathbb{R}^{d}$.

The classical lemma of Dvoretzky and Rogers [DR50] states that in a John decomposition of the identity, one can always find $d$ vectors such that the selected vectors are not too far from an orthonormal system.

Lemma 5.4 (Dvoretzky-Rogers lemma DR50]). Let $u_{1}, \ldots, u_{m} \in S^{d-1}$ and $c_{1}, \ldots, c_{m}>$ 0 such that (5.4) holds. Then there exists an orthonormal basis $b_{1}, \ldots, b_{d}$ of $\mathbb{R}^{d}$ and a subset $\left\{x_{1}, \ldots, x_{d}\right\} \subset\left\{u_{1}, \ldots, u_{m}\right\}$ with $x_{j} \in \operatorname{lin}\left\{b_{1}, \ldots, b_{j}\right\}$ and

$$
\sqrt{\frac{d-j-1}{d}} \leq\left\langle x_{j}, b_{j}\right\rangle \leq 1
$$

for $j=1, \ldots, d$.

Consider the parallelotope $P$ spanned by the selected $d$ vectors $x_{1}, \ldots, x_{d}$. The volume of $P$ is bounded from below by

$$
(\operatorname{Vol}(P))^{2}=\left[\operatorname{det}\left(x_{1}, \ldots, x_{d}\right)\right]^{2} \geq \frac{d !}{d^{d}} .
$$

The main results of this chapter are the following two statements. Theorem 5.5 is essentialy the same as Proposition 2.1 of Pelczyński and Szarek [PS91, however, here we give a probabilistic proof and interpretation. In Theorem 5.5 (ii) and (iii), we also note that when $m$ is small the improvement on the original Dvoretzky-Rogers bound is larger.

Theorem 5.5. Let $u_{1}, \ldots, u_{m} \in S^{d-1}$ be unit vectors satisfying (5.4) with some $c_{1}, \ldots$, $c_{m}>0$. Then there is a subset $\left\{x_{1}, \ldots, x_{d}\right\} \subset\left\{u_{1}, \ldots, u_{m}\right\}$ with

$$
\left[\operatorname{det}\left(x_{1}, \ldots, x_{d}\right)\right]^{2} \geq \gamma(d, \bar{m}) \cdot \frac{d !}{d^{d}},
$$

where $\gamma(d, \bar{m})=\frac{\bar{m}^{d}}{d !}\left(\begin{array}{c}\bar{m} \\ d\end{array}\right)^{-1}$, and $\bar{m}=\min \{m, d(d+1) / 2\}$.

Moreover, for $\gamma(d, \bar{m})$, we have 
(i) $\gamma(d, \bar{m}) \geq \gamma(d, d(d+1) / 2) \geq 3 / 2$ for any $d \geq 2$ and $m \geq d$. And $\gamma(d, d(d+1) / 2)$ is monotonically increasing, and $\lim _{d \rightarrow \infty} \gamma(d, d(d+1) / 2)=e$.

(ii) Fix $a c>1$, and consider the case when $m \leq c d$ with $c \geq 1+1 / d$. Then

$$
\gamma(d, m) \geq \gamma(d,\lceil c d\rceil) \sim \sqrt{\frac{c-1}{c}}\left(\frac{c-1}{c}\right)^{(c-1) d} e^{d}, \quad \text { as } d \rightarrow \infty .
$$

(iii) Fix an integer $k \geq 1$, and consider the case when $m \leq d+k$. Then

$$
\gamma(d, m) \geq \gamma(d, d+k) \sim \frac{k ! e^{k}}{\sqrt{2 \pi}} \frac{e^{d}}{(d+k)^{k+1 / 2}}, \text { as } d \rightarrow \infty .
$$

We note that in (ii) and (iii), the improvements are exponentially large in $d$ as $d$ tends to infinity.

The following statement provides a lower bound on the probability that $d$ independent, identically distributed random vectors selected from $\left\{u_{1}, \ldots, u_{m}\right\}$ according to the distribution determined by the weights $\left\{c_{1}, \ldots, c_{m}\right\}$ has large volume.

Proposition 5.6. Let $\lambda \in(0,1)$. With the notations and assumptions of Theorem 5.5, if we choose the vectors $x_{1}, \ldots, x_{d}$ independently according to the distribution $\mathbb{P}\left(x_{\ell}=u_{i}\right)=$ $c_{i} / d$ for each $\ell=1, \ldots, d$ and $i=1, \ldots, m$, then with probability at least $(1-\lambda) e^{-d}$, we have that

$$
\left[\operatorname{det}\left(x_{1}, \ldots, x_{d}\right)\right]^{2} \geq \lambda \gamma(d, \bar{m}) \cdot \frac{d !}{d^{d}}
$$

The geometric interpretation of Theorem 5.5 is the following. If $K$ is a convex polytope with $n$ facets, and $B^{d}$ is the maximal volume ellipsoid in $K$, then the number of contact points $u_{1}, \ldots, u_{m}$ in John's theorem is at most $m \leq n$. Thus, Theorem 5.5 yields a simplex in $K$ of not too small volume, with one vertex at the origin.

In particular, consider $k=1$ in Theorem 5.5 (iii), that is, when $K$ is the regular simplex whose inscribed ball is $B^{d}$. Then the John decomposition of the identity determined by $K$ consists of $d+1$ unit vectors that determine the vertices of a regular $d$-simplex inscribed in $B^{d}$, which we denote by $\Delta_{d}$, and note that $\operatorname{Vol}\left(\Delta_{d}\right)=(d+1)^{\frac{d+1}{2}} /\left(d^{d / 2} d !\right)$. Clearly, in this John decomposition of the identity, the volume of the simplex determined by any $d$ of the vectors $u_{1}, \ldots, u_{d+1}$ is

$$
\operatorname{Vol}\left(\Delta_{d}\right) /(d+1)=\frac{(d+1)^{\frac{d-1}{2}}}{d^{d / 2} d !} .
$$

By Theorem 5.5, we obtain that

$$
\max \left[\operatorname{det}\left(u_{i_{1}}, \ldots, u_{i_{d}}\right)\right]^{2} \geq \frac{(d+1)^{d-1}}{d !} \cdot \frac{d !}{d^{d}}=\frac{(d+1)^{d-1}}{d^{d}},
$$


which yields the same bound for the largest volume simplex as the right-hand-side of (5.8). Thus, Theorem 5.5 is sharp in this case.

We will use the following theorem in our argument.

Theorem 5.7 (|Joh48, Peł90, Bal92, GS05|). If a set of unit vectors satisfies (5.4) (resp., (5.4) and (5.5) with some positive scalars $c_{i}^{\prime}$, then a subset of $m$ elements also satisfies (5.4) (resp., (5.4) and (5.5) with some positive scalars $c_{i}$, where

$$
d+1 \leq m \leq d(d+1) / 2
$$

(resp., $d+1 \leq m \leq d(d+3) / 2)$.

In Section 5.4, we outline a proof of Theorem 5.7 for two reasons. First, we will use the part when only (5.4) is assumed, which is only implicitly present in GS05]. Second, in [GS05], the result is described in terms of the contact points of a convex body with its maximal volume ellipsoid, that is, in the context of John's theorem. We, on the other hand, would like to give a presentation where the linear algebraic fact and its use in convex geometry are separated. Nevertheless, our proof is very close to the one given in GS05.

\subsection{Proof of Lemma 5.2}

The idea of the proof is to slightly rotate each distribution so that the probability that the $d$ vectors are linearly independent is 1 . Then we may apply Pivovarov's lemma, and use a limit argument as the $d$ rotations each tend to the identity.

Let $A_{1}, \ldots, A_{d}$ be matrices in $S O(d)$ chosen independently of each other and of the $x_{i} \mathrm{~s}$ according to the unique Haar probability measure on $S O(d)$. Fix an arbitrary non-zero unit vector $e$ in $\mathbb{R}^{d}$. Note that $A_{i} x_{i} /\left|x_{i}\right|$ and $A_{i} e$ have the same distribution: both are uniformly chosen points of the unit sphere according to the uniform probability distribution on $S^{d-1}$. A bit more is true: the joint distribution of $A_{1} x_{1} /\left|x_{1}\right|, \ldots, A_{d} x_{d} /\left|x_{d}\right|$ and the joint distribution of $A_{1} e, \ldots, A_{d} e$ are the same: they are independently chosen, uniformly distributed points on the unit sphere. It follows that

$$
\mathbb{P}\left(A_{1} x_{1}, \ldots, A_{d} x_{d} \text { are lin. indep. }\right)=\mathbb{P}\left(A_{1} e, \ldots, A_{d} e \text { are lin. indep. }\right)=1 .
$$

Denote the Haar measure on $Z:=S O(d)^{d}$ by $\nu$. Thus, we have

$$
1=\mathbb{P}\left(A_{1} x_{1}, \ldots, A_{d} x_{d} \text { are lin. indep. }\right)=
$$




$$
\begin{aligned}
& \int_{Z} \int_{\mathbb{R}^{d}} \int_{\mathbb{R}^{d}} \ldots \int_{\mathbb{R}^{d}} \mathbb{1}_{\left\{A_{1} x_{1}, \ldots, A_{d} x_{d} \text { are lin. indep. }\right\}}\left(x_{1}, \ldots, x_{d}, A_{1}, \ldots, A_{d}\right) \\
& \mathrm{d} \mu_{1}\left(x_{1}\right) \ldots \mathrm{d} \mu_{d}\left(x_{d}\right) \mathrm{d} \nu\left(A_{1}, \ldots, A_{d}\right) \\
& =\int_{Z} \mathbb{P}\left(A_{1} x_{1}, \ldots, A_{d} x_{d} \text { are lin. indep. } \mid A_{1}, \ldots, A_{d}\right) \mathrm{d} \nu\left(A_{1}, \ldots, A_{d}\right),
\end{aligned}
$$

where $\mathbb{1}$ denotes the indicator function.

Thus,

$$
1=\mathbb{P}\left[\mathbb{P}\left(A_{1} x_{1}, \ldots, A_{d} x_{d} \text { are lin. indep. } \mid A_{1}, \ldots, A_{d}\right)=1\right] .
$$

We call a $d$-tuple $\left(A_{1}, \ldots, A_{d}\right) \in Z$ 'good' if $A_{1} x_{1}, \ldots, A_{d} x_{d}$ are linearly independent with probability 1 . In (5.10), we obtained that the set of not good elements of $Z$ is of measure zero.

Thus, we may choose a sequence $\left(A_{1}^{(j)}, A_{2}^{(j)}, \ldots, A_{d}^{(j)}\right), j=1,2, \ldots$ in $Z$, such that $\left\|A_{i}^{(j)}-\operatorname{Id}_{d}\right\|<1 / j$ for all $i$ and $j$, and $\left(A_{1}^{(j)}, \ldots, A_{d}^{(j)}\right)$ is good for each $j$.

Note that for any $j$,

$$
\left[\operatorname{det}\left(A_{1}^{(j)} x_{1}, \ldots, A_{d}^{(j)} x_{d}\right)\right]^{2} \leq\left|A_{1}^{(j)} x_{1}\right|^{2}\left|A_{2}^{(j)} x_{2}\right|^{2} \ldots\left|A_{d}^{(j)} x_{d}\right|^{2}
$$

and

$$
\mathbb{E}\left[\left|A_{1}^{(j)} x_{1}\right|^{2}\left|A_{2}^{(j)} x_{2}\right|^{2} \ldots\left|A_{d}^{(j)} x_{d}\right|^{2}\right]=d^{d}
$$

We conclude that

$$
\begin{gathered}
\mathbb{E}\left(\left[\operatorname{det}\left(x_{1}, \ldots, x_{d}\right)\right]^{2}\right)= \\
\mathbb{E}\left(\left[\operatorname{det} \lim _{j \rightarrow \infty}\left(A_{1}^{(j)} x_{1}, \ldots, A_{d}^{(j)} x_{d}\right)\right]^{2}\right) \stackrel{(a)}{=} \\
\mathbb{E}\left(\left[\lim _{j \rightarrow \infty} \operatorname{det}\left(A_{1}^{(j)} x_{1}, \ldots, A_{d}^{(j)} x_{d}\right)\right]^{2}\right) \stackrel{(b)}{=} \\
\lim _{j \rightarrow \infty} \mathbb{E}\left(\left[\operatorname{det}\left(A_{1}^{(j)} x_{1}, \ldots, A_{d}^{(j)} x_{d}\right)\right]^{2}\right),
\end{gathered}
$$

where, in (a), we use that the determinant is continuous. In (b), Lebesgue's Dominated Convergence Theorem may be applied by (5.11) and (5.12).

Fix $j$ and let $y_{1}=A_{1}^{(j)} x_{1}, \ldots, y_{d}=A_{d}^{(j)} x_{d}$. In order to emphasize that the assumption (5.2) is not needed, and also for completeness, we repeat Pivovarov's argument. For $k=1, \ldots, d-1$, let $P_{k}$ denote the orthogonal projection of $\mathbb{R}^{d}$ onto the linear subspace $\operatorname{span}\left\{y_{1}, \ldots, y_{k}\right\}^{\perp}$. Thus,

$$
\left|\operatorname{det}\left(y_{1}, \ldots, y_{d}\right)\right|=\left|y_{1}\right|\left|P_{1} y_{2}\right| \cdots\left|P_{d-1} y_{d}\right| \text {. }
$$

Note that with probability $1, \operatorname{rank} P_{k}=d-k$. It follows from $(5.1)$ that $\mathbb{E}\left|P_{k} y_{k+1}\right|^{2}=d-k$. Fubini's Theorem applied to 5.13 completes the proof of Lemma 5.2 . 


\subsection{Proofs of Theorem 5.5 and Proposition 5.6}

Let $u_{1}, \ldots u_{m} \in S^{d-1}$ be a set of vectors satisfying (5.4) with some positive weights $c_{1}, \ldots, c_{m}$. We set the probability of each vector $u_{i}, i=1, \ldots m$ as $p_{i}=c_{i} / d$, and obtain a discrete probability distribution.

Let $u_{i_{1}}, \ldots, u_{i_{d}}$ be independent random vectors from the set $u_{1}, \ldots, u_{m}$ chosen (with possible repetitions) according to the above probability distribution.

By Lemma 5.2, we have that

$$
\mathbb{E}\left(\left[\operatorname{det}\left(u_{i_{1}}, \ldots, u_{i_{d}}\right)\right]^{2}\right)=\frac{d !}{d^{d}} .
$$

Since the probability that the random vectors $u_{i_{1}}, \ldots, u_{i_{d}}$ are linearly dependent is positive,

$$
\max \left[\operatorname{det}\left(u_{i_{1}}, \ldots, u_{i_{d}}\right)\right]^{2}>\frac{d !}{d^{d}} .
$$

Our goal is to quantify this inequality by bounding from below the probability that the determinant is 0 . Let

$$
M^{2}:=\max \left[\operatorname{det}\left(u_{i_{1}}, \ldots, u_{i_{d}}\right)\right]^{2} .
$$

Note that if an element of $\left\{u_{1}, \ldots, u_{m}\right\}$ is selected at least twice, then $\operatorname{det}\left(u_{i_{1}}, \ldots, u_{i_{d}}\right)=0$. Thus,

$$
\mathbb{E}\left(\left[\operatorname{det}\left(u_{i_{1}}, \ldots, u_{i_{d}}\right)\right]^{2}\right) \leq M^{2} P_{1},
$$

where $P_{1}$ denotes the probability that all indices are pairwise distinct. Therefore,

$$
M^{2} \geq \frac{d !}{d^{d}} \cdot \frac{1}{P_{1}}
$$

Note that $P_{1}$ is a degree $d$ elementary symmetric function of the variables $p_{1}, \ldots, p_{m}$. Furthermore, $p_{1}+\ldots+p_{m}=1$ and $p_{i} \geq 0$ for all $i=1, \ldots, m$. It can easily be seen (using Lagrange multipliers, or by induction on $m$ ) that for fixed $m$ and $d$, the maximum of $P_{1}$ is attained when $p_{1}=\ldots=p_{m}=1 / m$. Thus,

$$
P_{1} \leq d !\left(\begin{array}{c}
m \\
d
\end{array}\right) \frac{1}{m^{d}}
$$

In summary,

$$
M^{2} \geq \frac{d !}{d^{d}} \cdot \frac{m^{d}}{d !}\left(\begin{array}{c}
m \\
d
\end{array}\right)^{-1} .
$$

First, we note that $\gamma(d, m):=\frac{m^{d}}{d !}\left(\begin{array}{c}m \\ d\end{array}\right)^{-1}$ is decreasing in $m$. Thus, by (5.9), we may assume that $m$ is as large as possible, that is, $m=\frac{d(d+1)}{2}$ proving the first part of Theorem 5.5. 


\subsubsection{Proof of Theorem 5.5 (i)}

Let $\gamma(d):=\gamma(d, d(d+1) / 2)$. We show that $\gamma(d)$ is increasing in $d$.

With the notation $m:=d(d+1) / 2$, we note that $(d+1)(d+2) / 2=m+d+1$. Thus,

$$
\frac{\gamma(d+1)}{\gamma(d)}=\frac{(m+d+1)^{d+1} m \cdots(m-d+1)}{m^{d}(m+d+1) \cdots(m+1)}=\frac{(m+d+1)^{d}}{m^{d}} \cdot \frac{m \cdots(m-d+1)}{(m+d) \cdots(m+1)}
$$

Thus, we need to show that

$$
1+\frac{d+1}{m}>\sqrt[d]{\left(1+\frac{d}{m}\right)\left(1+\frac{d}{m-1}\right) \cdots\left(1+\frac{d}{m-d+1}\right)},
$$

which, by the AM/GM inequality follows, if

$$
1+\frac{d+1}{m} \geq 1+d \frac{\frac{1}{m}+\frac{1}{m-1}+\ldots+\frac{1}{m-d+1}}{d}
$$

which is equivalent to

$$
\frac{d}{m} \geq \frac{1}{m-1}+\frac{1}{m-2}+\ldots+\frac{1}{m-d+1} .
$$

For this to hold, it is sufficient to show that for every integer or half of an integer $1 \leq i \leq d / 2$, we have that

$$
\frac{2 d}{(d-1) m} \geq \frac{1}{m-i}+\frac{1}{m-d+i} .
$$

After substituting $m=d(d+1) / 2$, it is easy to see that $(5.14)$ holds.

Finally, $\lim _{d \rightarrow \infty} \gamma(d)=e$ follows from Stirling's formula.

\subsubsection{Proof of Theorem 5.5 (ii) and (iii)}

Stirling's formula yields both claims.

\subsubsection{Proof of Proposition 5.6}

Let $X$ denote the random variable $X:=\left[\operatorname{det}\left(x_{1}, \ldots, x_{d}\right)\right]^{2}, \quad E:=\mathbb{E}(X)=$ $\frac{d !}{d^{d}}$, and $q:=\mathbb{P}\left(X \geq \frac{\lambda E}{P_{1}}\right)$, where, as in the proof of Theorem 5.5 $P_{1}:=$ $\mathbb{P}\left(x_{1}, \ldots, x_{d}\right.$ are pairwise distinct $)$.

In the proof of Theorem 5.5, we established

$$
P_{1} \leq(\gamma(d, \bar{m}))^{-1} \text {, and thus, } q \leq \mathbb{P}\left(\left[\operatorname{det}\left(x_{1}, \ldots, x_{d}\right)\right]^{2} \geq \lambda \gamma(d, \bar{m}) \cdot \frac{d !}{d^{d}}\right) .
$$


Using the fact that $X$ is at most one, we have

$$
E \leq \frac{\lambda E}{P_{1}} \mathbb{P}\left(X<\frac{\lambda E}{P_{1}} \text { and } x_{1}, \ldots, x_{d} \text { are pairwise distinct }\right)+\mathbb{P}\left(X \geq \frac{\lambda E}{P_{1}}\right) .
$$

That is, $E \leq \frac{\lambda E}{P_{1}}\left(P_{1}-q\right)+q$, and thus, by 5.15

$$
q \geq \frac{(1-\lambda) E}{1-\frac{\lambda E}{P_{1}}} \geq \frac{(1-\lambda) d !}{d^{d}-\lambda \gamma(d, \bar{m}) d !} \geq(1-\lambda) e^{-d}
$$

completing the proof of Proposition 5.6 .

\subsection{Proof of Theorem 5.7}

First, observe that (5.4) holds with some positive scalars $c_{i}$, if and only if, the matrix $\mathrm{Id}_{d} / d$ is in the convex hull of the set $\mathcal{A}=\left\{v_{i} \otimes v_{i}: i=1, \ldots, m\right\}$ in the

real vector space of $d \times d$ matrices. The set $\mathcal{A}$ is contained in the subspace of symmetric matrices with trace 1 , which is of dimension $d(d+1) / 2-1$. Carathéodory's theorem Sch14, Theorem 1.1.4] now yields the desired upper bound on $m$.

In the case when both (5.4) and (5.5) are assumed, we lift our vectors into $\mathbb{R}^{d+1}$ as follows. Let $\hat{v}_{i}=\sqrt{\frac{d}{d+1}}\left(v_{i}, 1 / \sqrt{d}\right) \in \mathbb{R}^{d+1}$. It is easy to check that $\left|\hat{v}_{i}\right|=1$, and that (5.4) holds for the vectors $\hat{v}_{i}$ with some positive scalars $\hat{c}_{i}$ if, and only if, (5.4) and (5.5) hold for the vectors $v_{i}$ with scalars $c_{i}=\frac{d}{d+1} \hat{c}_{i}$. Now, $\hat{v}_{i} \otimes \hat{v}_{i}, i=1, \ldots, m$ are symmetric $(d+1) \times(d+1)$ matrices of trace one, and their $(d+1, d+1)$ th entry is $1 /(d+1)$. The dimension of this subspace of $\mathbb{R}^{(d+1) \times(d+1)}$ is $d(d+3) / 2-1$, thus, again, by Carathéodory's theorem, the proof is complete. 


\section{Chapter 6}

\section{Summary}

\subsection{On the angle sum of lines}

This section is based on the paper [FVZ16b.

Consider $n$ lines in the $d$-dimensional Euclidean space $\mathbb{R}^{d}$ which all pass through the origin $o$. What is the maximum $S(n, d)$ of the sum of the pairwise (non-obtuse) angles formed by the lines? The conjectured optimal configuration consists of $k+1$ copies of $x_{1}, \ldots, x_{m}$ and $k$ copies of $x_{m+1}, \ldots, x_{d}$. The sum of the pairwise angles in this configuration is

$$
\left[\left(\begin{array}{l}
d \\
2
\end{array}\right) k^{2}+m k(d-1)+\left(\begin{array}{c}
m \\
2
\end{array}\right)\right] \frac{\pi}{2} .
$$

L. Fejes Tóth proved the conjecture in 3-dimensional space for $n \leq 6$ and gave an upper bound using a recursive formula: $S(n, 3) \leq n(n-1) \pi / 5$. This means that the sum of angles is asymptotically less than $n^{2} \pi / 5$ as $n \rightarrow \infty$. In our paper [FVZ16b|, we improved this upper bound to $3 n^{2} \pi / 16 \approx 0.589 \cdot n^{2}$, and later Bilyk and Matzke [BM19 further improved it to $\left(\frac{\pi}{4}-\frac{69}{100 d}\right) n^{2}$ as $n \rightarrow \infty$. We note that their result for $d=3$ gives asymptotically less than $0.556 \cdot n^{2}$ as $n \rightarrow \infty$. However, their bound is for general $d$.

Our contribution to this problem is summarized in the following theorem.

Theorem 2.1. Let $l_{1}, \ldots, l_{n}$ be lines in $\mathbb{R}^{3}$ which all pass through the origin. If we denote by $\varphi_{i j}$ the angle formed by $l_{i}$ and $l_{j}$, then

$$
\sum_{1 \leq i<j \leq n} \varphi_{i j} \leq\left\{\begin{array}{lll}
\frac{3}{2} k^{2} \cdot \frac{\pi}{2}, & \text { if } & n=2 k, \\
\frac{3}{2} k(k+1) \cdot \frac{\pi}{2}, & \text { if } & n=2 k+1 .
\end{array}\right.
$$

We first investigated the planar case. We say that a pencil of lines is balanced if for every line the number of other lines making a positive angle (smaller than $\pi / 2$ ) and the number of other lines making a negative angle differ by at most one. 
Theorem 2.2. Let $l_{1}, \ldots, l_{n}$ be lines in $\mathbb{R}^{2}$ which all pass through the origin. If we denote by $\varphi_{i j}$ the angle formed by $l_{i}$ and $l_{j}$, then

$$
\sum_{1 \leq i<j \leq n} \varphi_{i j} \leq\left\{\begin{array}{lll}
k^{2} \cdot \frac{\pi}{2}, & \text { if } & n=2 k, \\
k(k+1) \cdot \frac{\pi}{2}, & \text { if } & n=2 k+1 .
\end{array}\right.
$$

Equality holds if, and only if, $l_{1}, \ldots, l_{n}$ is balanced.

Let $\mathbf{v}_{1}, \mathbf{v}_{2}$ be vectors and $\varphi$ the angle between them. Then for the 3-dimensional case we first define the function

$$
I:[0, \pi / 2] \rightarrow \mathbb{R}, \quad I(\varphi):=\frac{1}{4 \pi} \int_{S^{2}} \varphi_{*}^{\mathbf{u}}\left(\mathbf{v}_{1}, \mathbf{v}_{2}\right) \mathrm{d} \mathbf{u}
$$

where $\varphi_{*}^{\mathbf{u}}\left(\mathbf{v}_{1}, \mathbf{v}_{2}\right)$ is the angle between the perpendicular components of the vectors $\mathbf{v}_{1}$ and $\mathbf{v}_{2}$ to $\mathbf{u}$, or the complement of that angle (to $\pi$ ), whichever is smaller. $I(\varphi)$ is the average angle of the orthogonal projections of the lines to a plane with normal vector $\mathbf{u}$.

Next, we show, with the help of two lemmas, that $I(\varphi) \geq 2 \varphi / 3$ for all $\varphi \in[0, \pi / 2]$. The first lemma states that this holds at the end points of the domain, that is, for $\varphi=0$ and $\varphi=\pi / 2$.

Lemma 2.4. With the notation introduced above,

$$
I(0)=0 \quad \text { and } \quad I(\pi / 2)=\pi / 3 .
$$

The second lemma shows that $I$ is concave. The combination of the two statements clearly proves our claim.

Lemma 2.5. The function $I(\varphi)$ is concave on $[0, \pi / 2]$, and

$$
I(\varphi) \geq 2 \varphi / 3 \quad \text { for } \quad 0 \leq \varphi \leq \pi / 2
$$

From these results our main theorem follows directly. Since the average of the sum of the pairwise angles of the projections (the average taken with respect to the normal vector of the projecting plane) is at least $2 / 3$ times the sum of the original angles, there exist a $\mathbf{u}_{0}$ such that if we project the lines to the plane with normal vector $\mathbf{u}_{0}$ then the sum of the angles formed by the projections is greater than $2 / 3$ times the sum of the angles formed by the lines. Finally we know the optimum for the planar case and hence Theorem 2.1 holds. 


\subsection{Covering the sphere by equal zones}

This section is based on the paper FVZ16a.

The main problem investigated in this section originates form L. Fejes Tóth's paper FT73 and it is the focus of this section.

Problem (3.1). For a given $n$, find the smallest number $w_{n}$ such that one can cover $S^{2}$ with $n$ zones of half-width $w_{n}$. Find also the optimal configurations of zones that realize the optimal coverings.

Before our work the only known general lower bound was a trivial one: The sum of the areas of the zones must be at least $4 \pi$, so the common half-width of the zones needs to be at least $\arcsin (1 / n)$. This trivial lower bound is of course not sharp in case $n \geq 2$, since any two zones intersect, so their contribution to the covering (starting with the second one) cannot be their whole area.

We consider a covering as it is being built up zone by zone and investigate the contribution of each zone (which is less than its area) to the covering. Estimating the area of the intersection of two zones, depending on the half-width and angle, we give an upper bound for the contribution of each zone, and, in turn, a lower bound for $w_{n}$ which is better than the trivial one.

Let $2 F(w, \alpha)$ denote the area of intersection of two zones. For $n \geq 3$, let $d_{n}$ denote the maximum of the minimal pairwise (spherical) distances of $n$ points on the unit sphere $S^{2}$. For a few values of $n$ the exact value of $d_{n}$ is known, for others, we are going to use estimations. Let $\delta_{n}^{*}$ denote the smaller of $\pi / 2$ and the exact value or the best known upper bound of $d_{n}$.

For $0 \leq \alpha \leq \pi / 2$ and $n \geq 3$ we introduce $f(w, \alpha)=4 \pi \sin w-2 F(w, \alpha)$ and

$$
G(w, n)=4 \pi \sin w+\sum_{i=2}^{n} f\left(w, \delta_{2 i}^{*}\right) .
$$

Lemma (3.5). For a fixed $n \geq 3$, the function $G(w, n)$ is continuous and monotonically increasing in $w$ in the interval $\left[0, \delta_{2 n}^{*} / 3\right]$. Furthermore, $G(0, n)=0$ and $G\left(\delta_{2 n}^{*} / 3, n\right) \geq 4 \pi$.

All of the above leads us to our main theorem.

Theorem (3.6). For $n \geq 3$, let $w_{n}^{*}$ denote the unique solution of the equation $G(w, n)=$ $4 \pi$ in the interval $\left[0, \delta_{2 n}^{*} / 3\right]$. Then $\arcsin (1 / n)<w_{n}^{*} \leq w_{n}$. 


\subsection{On the multiplicity of arrangements of congruent zones on the sphere}

This section is based on the paper [BFVZ17].

In this section we examine arrangements of equal zones on $S^{d-1}$ from the point of view of multiplicity. The multiplicity of an arrangement is the maximum number of zones the points of the sphere belong to. We seek to minimize the multiplicity for given $d$ and $n$ as a function of the common width of the zones. First, we want to find upper bounds on the multiplicity. For this, we need the following definitions.

Let $\alpha: \mathbb{N} \rightarrow(0,1]$ be a positive real function with $\lim _{n \rightarrow \infty} \alpha(n)=0$. For a positive integer $d \geq 3$, let $m_{d}=\sqrt{2 \pi d}+1$. Let $k: \mathbb{N} \rightarrow \mathbb{N}$ be a function that satisfies the limit condition

$$
\limsup _{n \rightarrow \infty} \alpha(n)^{-(d-1)}\left(\frac{e C_{d}^{*} n \alpha(n)}{k(n)}\right)^{k(n)}=\beta<1,
$$

where $C_{d}^{*}$ is a suitable constant depending only on the dimension.

Theorem 4.2). For each positive integer $d \geq 3$, and any real function $\alpha(n)$ described above, for sufficiently large $n$, there exists an arrangement of $n$ zones of spherical halfwidth $m_{d} \alpha(n)$ on $S^{d-1}$ such that no point of $S^{d-1}$ belongs to more than $k(n)$ zones.

The following statement provides the wanted upper bound on the multiplicity of coverings of the $d$-dimensional unit sphere by $n$ congruent zones.

Theorem 4.3). For each positive integer $d \geq 3$, there exists a positive constant $A_{d}$ such that for sufficiently large $n$, there is a covering of $S^{d-1}$ by $n$ zones of half-width $m_{d} \frac{\ln n}{n}$ such that no point of $S^{d-1}$ belongs to more than $A_{d} \ln n$ zones.

There is an obviously large gap between the lower and upper bounds for the multiplicity. The problem of finding the minimum multiplicity for zone coverings of $S^{d-1}$ remains open.

\subsection{On the volume bound in the Dvoretzky-Rogers lemma}

This section is based on the paper [FNZ18].

We say that a measure $\mu$ is an isotropic measure if it is a probability measure on $\mathbb{R}^{d}$ with the following two properties. First its inertia tensor is the identity matrix 


$$
\int_{\mathbb{R}^{d}} x \otimes x \mathrm{~d} \mu(x)=\mathrm{Id}_{d}
$$

and its center of mass of $\mu$ is at the origin, that is,

$$
\int_{\mathbb{R}^{d}} x \mathrm{~d} \mu(x)=0 .
$$

The Dvoretzky-Rogers lemma states that one may select a $d$-subset of any isotropic vector set in $\mathbb{R}^{d}$ such that the subset is well spread out, which means that the volume of the spanned parallelepiped is large. Consequently the determinant is at least $\sqrt{d ! / d^{d}}$. On the other hand we can choose the $d$ vectors randomly then compute the expectation of the square of the resulting determinant.

We extended Pivovarov's result $\mid \overline{P i v 10}$ to a wider class of measures to obtain the improved lower bound of Pełczyński and Szarek PS91 on the maximum of the volume of the spanned parallelotope and also we give a probabilistic interpretation of the volume bound in the Dvoretzky-Rogers lemma. Our extension allows us to apply it for discrete isotropic measures.

Lemma (5.2). Let $x_{1}, \ldots, x_{d}$ be independent random vectors distributed according to the measures $\mu_{1}, \ldots, \mu_{d}$ in $\mathbb{R}^{d}$ satisfying (5.1). Assume that $\mu_{i}(\{0\})=0$ for $i=1, \ldots, d$. Then

$$
\mathbb{E}\left(\left[\operatorname{det}\left(x_{1}, \ldots, x_{d}\right)\right]^{2}\right)=d !
$$

holds.

The geometric motivation in studying isotropic measures is the celebrated theorem of John JJoh48, 5.3, which states that there exists a unique maximal volume ellipsoid in any convex body, and characterizes, that this ellipsoid is the unit ball if and only if a subset of the contact points with certain weights form a discrete isotropic measure. If a set of unit vectors $\left(u_{1}, \ldots u_{m}\right)$ along with positive constants satisfies the two conditions in John's theorem then we say those vectors form a John decomposition of the identity.

The classical lemma of Dvoretzky and Rogers [DR50], 5.4 stated that in a John decomposition of the identity we can always find $d$ vectors such that they are not too far from an orthonormal system, where not too far means that if the parallelotope $P$ spanned by the selected $d$ vectors $x_{1}, \ldots, x_{d}$ has volume $\operatorname{Vol}(P)$, then the following holds.

$$
(\operatorname{Vol}(P))^{2}=\left[\operatorname{det}\left(x_{1}, \ldots, x_{d}\right)\right]^{2} \geq \frac{d !}{d^{d}}
$$

Our main results in this topic are the following two Theorems, the first of which is essentially the same as Pelczyński and Szarek's [PS91, however with a probabilistic approach, proof and interpretation. 
Theorem 5.5). Let $u_{1}, \ldots, u_{m} \in S^{d-1}$ be unit vectors satisfying (5.4) with some $c_{1}, \ldots$, $c_{m}>0$. Then there is a subset $\left\{x_{1}, \ldots, x_{d}\right\} \subset\left\{u_{1}, \ldots, u_{m}\right\}$ with

$$
\left[\operatorname{det}\left(x_{1}, \ldots, x_{d}\right)\right]^{2} \geq \gamma(d, \bar{m}) \cdot \frac{d !}{d^{d}}
$$

where $\gamma(d, \bar{m})=\frac{\bar{m}^{d}}{d !}\left(\begin{array}{c}\bar{m} \\ d\end{array}\right)^{-1}$, and $\bar{m}=\min \{m, d(d+1) / 2\}$.

Moreover, for $\gamma(d, \bar{m})$, we have

(i) $\gamma(d, \bar{m}) \geq \gamma(d, d(d+1) / 2) \geq 3 / 2$ for any $d \geq 2$ and $m \geq d$. And $\gamma(d, d(d+1) / 2)$ is monotonically increasing, and $\lim _{d \rightarrow \infty} \gamma(d, d(d+1) / 2)=e$.

(ii) Fix a $c>1$, and consider the case when $m \leq c d$ with $c \geq 1+1 / d$. Then

$$
\gamma(d, m) \geq \gamma(d,\lceil c d\rceil) \sim \sqrt{\frac{c-1}{c}}\left(\frac{c-1}{c}\right)^{(c-1) d} e^{d}, \quad \text { as } d \rightarrow \infty .
$$

(iii) Fix an integer $k \geq 1$, and consider the case when $m \leq d+k$. Then

$$
\gamma(d, m) \geq \gamma(d, d+k) \sim \frac{k ! e^{k}}{\sqrt{2 \pi}} \frac{e^{d}}{(d+k)^{k+1 / 2}}, \text { as } d \rightarrow \infty .
$$

The following statement, which is our second main result, provides a lower bound on the probability that $d$ independent, identically distributed random vectors selected from $\left\{u_{1}, \ldots, u_{m}\right\}$ according to the distribution determined by the weights $\left\{c_{1}, \ldots, c_{m}\right\}$ has large volume.

Proposition (5.6). Let $\lambda \in(0,1)$. With the notations and assumptions of Theorem 5.5, if we choose the vectors $x_{1}, \ldots, x_{d}$ independently according to the distribution $\mathbb{P}\left(x_{\ell}=u_{i}\right)=$ $c_{i} / d$ for each $\ell=1, \ldots, d$ and $i=1, \ldots, m$, then with probability at least $(1-\lambda) e^{-d}$, we have that

$$
\left[\operatorname{det}\left(x_{1}, \ldots, x_{d}\right)\right]^{2} \geq \lambda \gamma(d, \bar{m}) \cdot \frac{d !}{d^{d}}
$$




\section{7. fejezet}

\section{Összefoglaló}

\subsection{Egyenesek szögösszegei}

Ezen fejezet alapja a FVZ16b cikk.

Tekintsünk $n$ egyenest a $d$-dimenziós $\mathbb{R}^{d}$ euklideszi térben, melyek mindegyike átmegy az $o$ origón. Mi az $S(n, d)$-vel jelölt maximális összege az egyenespárok által meghatározott nemtompa szögeknek? A sejtett optimális konfigurációban egy ortonormált bázis elemeit az egyenesek irányvektorainak használjuk úgy, hogy minden bázisvektorhoz $\lfloor n / d\rfloor$ vagy $\lfloor n / d\rfloor+1$ vektor tartozik. Pontosabban, ha $n=k \cdot d+m(1 \leq m<d)$ az egyenesek száma, $x_{1}, \ldots, x_{d}$ pedig egy derékszögú koordináta rendszer tengelyei $\mathbb{R}^{d}$-ben, akkor az optimálisnak sejtett konfigurációban $k+1$-szer vesszük az $x_{1}, \ldots, x_{m}$-hez tartozó egyeneseket, és $k$-szor az $x_{m+1}, \ldots, x_{d}$-hez tartozókat. Ekkor a szögek összege

$$
\left[\left(\begin{array}{l}
d \\
2
\end{array}\right) k^{2}+m k(d-1)+\left(\begin{array}{c}
m \\
2
\end{array}\right)\right] \frac{\pi}{2} .
$$

Fejes Tóth László igazolta a sejtést 3 dimenzióban legfeljebb $6(n \leq 6)$ egyenes esetén, és adott egy felsô korlátot egy rekurzív formula segítségével: $S(n, 3) \leq n(n-1) \pi / 5$. Eszerint az egyenesek szögeinek összege aszimptotikusan legfeljebb $n^{2} \pi / 5$ amint $n \rightarrow \infty$. FVZ16b cikkünkben megjavítottuk ezt az aszimptotikus korlátot $3 n^{2} \pi / 16 \approx 0.589 \cdot n^{2}$-re, amit Bilyk és Matzke BM19 tovább javítottak $\left(\frac{\pi}{4}-\frac{69}{100 d}\right) n^{2}$-re, amint $n \rightarrow \infty$, amiból az is látható, hogy eredményük minden dimenzióban ad egy felső korlátot. Ez a felső korlát $d=3$ esetén $0.556 \cdot n^{2}$ ha $n \rightarrow \infty$

A problémakörben elért eredményeinket az alábbi tétel foglalja össze.

Tétel (2.1). Legyenek $l_{1}, \ldots, l_{n}$ egyenesek $\mathbb{R}^{3}$-ban, melyek mindegyike átmegy az origón. 
Jelölje $\varphi_{i j}$ az $l_{i}$ és $l_{j}$ által bezárt szöget. Ekkor

$$
\sum_{1 \leq i<j \leq n} \varphi_{i j} \leq\left\{\begin{array}{lll}
\frac{3}{2} k^{2} \cdot \frac{\pi}{2}, & h a & n=2 k, \\
\frac{3}{2} k(k+1) \cdot \frac{\pi}{2}, & h a & n=2 k+1 .
\end{array}\right.
$$

Tekintsük először a síkbeli esetet. A következô tétel valószínúleg munkánk előtt is ismert volt, de mivel nem találtunk rá bizonyítást az irodalomban, ezért úgy döntöttünk, hogy mi magunk is bebizonyítjuk. Azt mondjuk, hogy egy sugársor kiegyensúlyozott, ha minden egyenesre igaz, hogy a vele pozitív ( $\pi / 2$-nél kisebb) szöget bezáró, illetve a vele negatív szöget bezáró egyenesek számának különbsége legfeljebb 1.

Tétel 2.2. Legyenek $l_{1}, \ldots, l_{n}$ egyenesek $\mathbb{R}^{2}$-ben, melyek mindegyike átmegy az origón. Jelölje $\varphi_{i j}$ az $l_{i}$ és $l_{j}$ által meghatározott szöget. Ekkor

$$
\sum_{1 \leq i<j \leq n} \varphi_{i j} \leq\left\{\begin{array}{lll}
k^{2} \cdot \frac{\pi}{2}, & h a & n=2 k, \\
k(k+1) \cdot \frac{\pi}{2}, & h a & n=2 k+1 .
\end{array}\right.
$$

Továbbá pontosan akkor van egyenlóség, ha a sugársor kiegyensúlyozott.

Legyenek $\mathbf{v}_{1}, \mathbf{v}_{2}$ vektorok, $\varphi$ pedig a közbezárt szögük. Ekkor a 3 dimenziós eset tárgyalásához először is szükségünk lesz a következő függvényre:

$$
I:[0, \pi / 2] \rightarrow \mathbb{R}, \quad I(\varphi):=\frac{1}{4 \pi} \int_{S^{2}} \varphi_{*}^{\mathbf{u}}\left(\mathbf{v}_{1}, \mathbf{v}_{2}\right) \mathrm{d} \mathbf{u}
$$

ahol $\varphi_{*}^{\mathbf{u}}\left(\mathbf{v}_{1}, \mathbf{v}_{2}\right)$ a $\mathbf{v}_{1}$ és $\mathbf{v}_{2}$ vektorok $\mathbf{u}$ normálisú síkra vett vetületeinek a bezárt szöge, illetve ezen szög ( $\pi$-re) kiegészítô szöge közül a nem nagyobb. $I(\varphi)$ az u normálisú síkra vett vetületek által bezárt szögek átlaga. Ezután megmutatjuk két lemma segítségével, hogy $I(\varphi) \geq 2 \varphi / 3$ minden $\varphi \in[0, \pi / 2]$ esetén. Az első lemma ezt a végpontokban igazolja, azaz ha $\varphi=0$ és $\varphi=\pi / 2$.

Lemma (2.4). A fenti jelöléseket használva,

$$
I(0)=0, \quad \text { illetve } \quad I(\pi / 2)=\pi / 3 .
$$

A második lemma segítségével megmutatjuk, hogy I konkáv, s így állításunk teljesül. Lemma (2.5). Az I $(\varphi)$ függvény konkáv $[0, \pi / 2]-n$, és

$$
I(\varphi) \geq 2 \varphi / 3 \quad \text { ha } \quad 0 \leq \varphi \leq \pi / 2 .
$$

Ezekből a 2.1 Tétel közvetlenül következik. Mivel a vetületek szögeinek átlaga (a vetítôsík normálvektorára átlagolva) legalább 2/3-a az eredeti szögek összegének, így létezik egy $\mathbf{u}_{0}$, hogy ezen normálvektorú síkra vetítve a vektorokat a szögösszeg több, mint 2/3-a az eredeti szögösszegnek. Végül mivel az optimum ismert a síkbeli esetben, így a tételt igazoltuk. 


\subsection{Gömbfedés egybevágó zónákkal}

Ezen fejezet alapja a |FVZ16a cikk.

Az ebben a fejezetben vizsgált fő kérdés Fejes Tóth Lászlótól [FT73] ered, és a következóképp hangzik.

Probléma 3.1). Adott $n$ esetén keressük a legkisebb $w_{n}$ számot, melyre igaz, hogy $S^{2}$ lefedhetố $n$ egyforma $w_{n}$ félszélességú zónával. Határozzuk meg továbbá azt az optimális konfigurációt, mely megvalósítja ezt a fedést.

Munkánk elótt az egyetlen ismert alsó korlát a triviális volt, miszerint a zónák területének összege ki kell, hogy adja a $4 \pi$-t, a gömb felszínét. Természetesen ez az alsó korlát nem éles, mivel már két zóna esetén igaz, hogy bármely két zónának van metszete, így a másodiktól kezdve semelyik sem járul hozzá a fedéshez teljes területével. Megjegyezzük továbbá, hogy a probléma megoldott volt $n=3,4$ zóna esetén Rosta Ros72 és Linhart Lin74 munkája nyomán.

Tekintsünk egy fedésre úgy, mint ha zónánként építenénk fel, és nézzük meg a tényleges hozzájárulását a fedéshez (ami a második zónától kezdve szigorúan kisebb, mint a zóna területe). Két zóna metszetének területét tudjuk becsülni a szélesség és a fóköreik által bezárt szög ismeretében, így a triviálisnál jobb alsó korlátot adhatunk a minimumra.

Jelölje $2 F(w, \alpha)$ két zóna metszetét. Ekkor $n \geq 3$-ra legyen $d_{n}$ az $n$ gömbön elhelyezett pont közötti minimális távolság maximuma. Néhány $n$-re ismert $d_{n}$ pontos értéke, míg másokra becslést kell használnunk. Legyen $\delta_{n}^{*} d_{n}$ pontos értéke (ha ismert), vagy legjobb felsố becslése (ha nem) és $\pi / 2$ közül a kisebb.

Bevezetjük $0 \leq \alpha \leq \pi / 2$ és $n \geq 3$ esetén az $f(w, \alpha)=4 \pi \sin w-2 F(w, \alpha)$, illetve a

$$
G(w, n)=4 \pi \sin w+\sum_{i=2}^{n} f\left(w, \delta_{2 i}^{*}\right) .
$$

függvényeket. A $G(w, n)$ függvény alulról becsüli a bemutatott gondolatmenet alapján $n$ w szélességú zóna hozzájárulását a fedéshez.

Lemma (3.5). Rögzített $n \geq 3$ esetén $G(w, n)$ folytonos és monoton növekvố $w$-ben a $\left[0, \delta_{2 n}^{*} / 3\right]$ intervallumon. Továbbá $G(0, n)=0$ és $G\left(\delta_{2 n}^{*} / 3, n\right) \geq 4 \pi$.

A fentiek segítségével már ki tudjuk mondani fó eredményünket:

Tétel (3.6). Jelölje $w_{n}^{*} n \geq 3$ esetén $a G(w, n)=4 \pi$ egyenlet egyetlen megoldását a $\left[0, \delta_{2 n}^{*} / 3\right]$ intervallumon. Ekkor $\arcsin (1 / n)<w_{n}^{*} \leq w_{n}$. 


\subsection{Egybevágó zónákból álló elrendezések multiplicitá-}

sa

Ezen fejezet alapja a BFVZ17 cikk.

Az előzô részből ismert egybevágó zónákból álló elrendezéseket ebben a részben multiplicitás szempontjából vizsgáljuk az $S^{d-1}$ gömbön. Egy elhelyezés multiplicitásán azt a legnagyobb számot értjük, melyre igaz, hogy a gömb valamely pontja ennyi zónához tartozik. Adott $d$ és $n$ mellett az $n$ zóna közös szélességének függvényében szeretnénk minimalizálni a multiplicitást. Ehhez a következô definíciókra van szükségünk

Legyen $\alpha: \mathbb{N} \rightarrow(0,1]$ egy pozitív valós függvény, melyre $\lim _{n \rightarrow \infty} \alpha(n)=0$. Ekkor $d \geq 3$ egészre, legyen $m_{d}=\sqrt{2 \pi d}+1$. Legyen továbbá $k: \mathbb{N} \rightarrow \mathbb{N}$ olyan függvény, mely kielégíti a következôt.

$$
\limsup _{n \rightarrow \infty} \alpha(n)^{-(d-1)}\left(\frac{e C_{d}^{*} n \alpha(n)}{k(n)}\right)^{k(n)}=\beta<1,
$$

ahol $C_{d}^{*}$ egy csak a dimenziótól függő megfelelő konstans.

Tétel (4.2). Minden $d \geq 3$ pozitiv egészre, $\alpha(n)$ fentebb definiált függvényre és elég nagy $n$-re létezik $n m_{d} \alpha(n)$ gömbi félszélességú zónából álló elrendezés $S^{d-1}$-en úgy, hogy $S^{d-1}$ semelyik pontja sem része $k(n)$-nél több zónának.

A következô állítás szolgáltatja a kívánt felsô korlátot a $d$-dimenziós gömb egybevágó sávokkal történő fedéseinek multiplicitására.

Tétel (4.3). Minden $d \geq 3$ egészre létezik pozitiv konstans $A_{d}$, bármely elég nagy $n$-re található $S^{d-1}$ fedése n egybevágó $m_{d} \frac{\ln n}{n}$ szélességú zónával úgy, hogy $S^{d-1}$ semelyik pontja sem tartozik $A_{d} \ln n$-nél több zónához.

Egy nyilvánvalóan nagy hézag van a multiplicitásra adott alsó és felsô korlátok között. Egy zónákkal való fedés minimális multiplicitása továbbra is nyitott kérdés $S^{d-1}$-en.

\subsection{A Dvoretzky-Rogers lemmában szereplő térfogat- korlát}

Ezen fejezet alapja a FNZ18 cikk.

Azt mondjuk, hogy a $\mu$ izotróp mérték, ha olyan valószínúségi mérték $\mathbb{R}^{d}$-n, mely teljesíti a következő feltételeket. 


$$
\int_{\mathbb{R}^{d}} x \otimes x \mathrm{~d} \mu(x)=\mathrm{Id}_{d}
$$

illetve:

$$
\int_{\mathbb{R}^{d}} x \mathrm{~d} \mu(x)=0
$$

A Dvoretzky-Rogers lemma azt mondja ki, hogy bármilyen $\mathbb{R}^{d}$-beli véges izotróp vektorhalmazból kiválasztható $d$ elem úgy, hogy az a részhalmaz elég nagy térfogatú paralelotópot feszít ki. Ennek következménye, hogy az általuk meghatározott determináns abszolút értéke legalább $\sqrt{d ! / d^{d}}$. Másfelól kiválasztható $d$ vektor véletlenszerúen, ahogy Pivovarov Piv10 cikkében olvasható, és kiszámolható a determináns négyzetének várhatóértéke is. Mi az ô eredményét terjesztjük ki mértékek egy bôvebb családjára, így eljutva Pelczyński és Szarek PS91 becsléséhez, valamint egy valószínúségi értelmezést adva a Dvoretzky-Rogers lemmában szereplő térfogatkorlátra.

Lemma 5.2. Legyenek $x_{1}, \ldots, x_{d}$ független véletlen vektorok a $\mu_{1}, \ldots, \mu_{d}$ in $\mathbb{R}^{d}$ valószinüségi mértékek szerint melyek kielégitik (5.1)-t. Tegyük fel, hogy $\mu_{i}(\{0\})=0, i=$ $1, \ldots, d$ esetén. Ekkor

$$
\mathbb{E}\left(\left[\operatorname{det}\left(x_{1}, \ldots, x_{d}\right)\right]^{2}\right)=d !
$$

A geometriai motiváció az izotróp mértékek tanulmányozásához John híres tételében |Joh48, 5.3 keresendô, mely azt mondja ki, hogy bármely konvex testbe írható egyértelmúen egy legnagyobb térfogatú ellipszoid, és karakterizálja, hogy ez pontosan akkor az egységgömb, ha az érintkezési pontok egy részhalmaza valamely pozitív súlyokkal diszkrét izotróp mértéket alkot. Ha egységvektorok egy halmaza valamilyen pozitív konstansokkal kielégíti a John tételében szereplő két feltételt, akkor azt mondjuk, hogy ezek egy John-féle egységfelbontást képeznek.

Dvoretzky és Rogers híres lemmája [DR50], 5.4 azt mondja ki, hogy egy John-féle egységfelbontásban mindig található $d$ vektor úgy, hogy azok ne legyenek túl messze, egy ortonormált bázistól, azaz az általuk kifeszített $P$ paralelotóp térfogatára

$$
(\operatorname{Vol}(P))^{2}=\left[\operatorname{det}\left(x_{1}, \ldots, x_{d}\right)\right]^{2} \geq \frac{d !}{d^{d}}
$$

teljesül.

A következő két tétel munkánk fő eredménye. Az első lényegében Pelczyński és Szarek PS91 becslése, csak valószínúségi megközelítésben illetve bizonyítással, ezáltal új értelmezést is adva a tételnek. 
Tétel 5.5). Legyenek $u_{1}, \ldots, u_{m} \in S^{d-1}$ egységvektorok, melyek kielégítik (5.4)-t a $c_{1}, \ldots, c_{m}>0$ konstansokkal. Ekkor léteznek $\left\{x_{1}, \ldots, x_{d}\right\} \subset\left\{u_{1}, \ldots, u_{m}\right\}$ vektorok a rendszerból, hogy

$$
\left[\operatorname{det}\left(x_{1}, \ldots, x_{d}\right)\right]^{2} \geq \gamma(d, \bar{m}) \cdot \frac{d !}{d^{d}},
$$

ahol $\gamma(d, \bar{m})=\frac{\bar{m}^{d}}{d !}\left(\begin{array}{c}\bar{m} \\ d\end{array}\right)^{-1}$, és $\bar{m}=\min \{m, d(d+1) / 2\}$.

Továbbá $\gamma(d, \bar{m})$-re igazak:

(i) $\gamma(d, \bar{m}) \geq \gamma(d, d(d+1) / 2) \geq 3 / 2$ bármely $d \geq 2$-re és $m \geq d$-re. Ezen felül $\gamma(d, d(d+1) / 2)$ monoton növekvố és $\lim _{d \rightarrow \infty} \gamma(d, d(d+1) / 2)=e$.

(ii) Rögzített $c>1$-re legyen $m \leq c d$, hogy $c \geq 1+1 / d$. Ekkor

$$
\gamma(d, m) \geq \gamma(d,\lceil c d\rceil) \sim \sqrt{\frac{c-1}{c}}\left(\frac{c-1}{c}\right)^{(c-1) d} e^{d}, \quad \text { as } d \rightarrow \infty .
$$

(iii) Rögzített $k \geq 1$ konstansra legyen $m \leq d+k$. Ekkor

$$
\gamma(d, m) \geq \gamma(d, d+k) \sim \frac{k ! e^{k}}{\sqrt{2 \pi}} \frac{e^{d}}{(d+k)^{k+1 / 2}}, \text { amint } d \rightarrow \infty .
$$

A következô állítás ad egy alsó korlátot annak valószínúségére, hogy d független, azonos eloszlású vektor az $\left\{u_{1}, \ldots, u_{m}\right\}$ halmazból $\left\{c_{1}, \ldots, c_{m}\right\}$ súlyokkal nagy térfogatú legyen.

Állítás 5.6). Legyen $\lambda \in(0,1)$. Ekkor az 5.5 Tétel feltételei és jelölései szerint, ha az $x_{1}, \ldots, x_{d}$ vektorokat függetlenül választjuk a $\mathbb{P}\left(x_{\ell}=u_{i}\right)=c_{i} / d$ eloszlás szerint $(\ell=1, \ldots, d$ és $i=1, \ldots, m)$, akkor legalább $(1-\lambda) e^{-d}$ valószínúséggel

$$
\left[\operatorname{det}\left(x_{1}, \ldots, x_{d}\right)\right]^{2} \geq \lambda \gamma(d, \bar{m}) \cdot \frac{d !}{d^{d}} .
$$




\section{Chapter 8}

\section{The author's publications}

[FNZ18] F. Fodor, M. Naszódi, and T. Zarnócz, On the volume bound in the Dvoretzky-Rogers lemma, Pacific J. Math. (2018), accepted for publication. arXiv:1804.03444.

[BFVZ17] A. Bezdek, F. Fodor, V. Vígh, and T. Zarnócz, On the multiplicity of arrangements of congruent zones on the sphere (2017), submitted for publication. arXiv:1705.02172.

[FVZ16a] F. Fodor, V. Vígh, and T. Zarnócz, Covering the sphere by equal zones, Acta Math. Hungar. 149 (2016), no. 2, 478-489, DOI 10.1007/s10474-016-0613-2. MR3518649

[FVZ16b] F. Fodor, V. Vígh, and T. Zarnócz, On the angle sum of lines, Arch. Math. (Basel) 106 (2016), no. 1, 91-100, DOI 10.1007/s00013-015-0847-1. MR3451371 


\section{Bibliography}

[Bal92] K. Ball, Ellipsoids of maximal volume in convex bodies, Geom. Dedicata 41 (1992), no. 2, 241-250.

[Bal97] K. Ball, An elementary introduction to modern convex geometry, Flavors of geometry, Math. Sci. Res. Inst. Publ., vol. 31, Cambridge Univ. Press, Cambridge, 1997, pp. 1-58.

[Ban51] T. Bang, A solution of the "plank problem.", Proc. Amer. Math. Soc. 2 (1951), 990-993.

[Ban50] T. Bang, On covering by parallel-strips, Mat. Tidsskr. B. 1950 (1950), 49-53.

[BKP84] I. Bárány, M. Katchalski, and J. Pach, Helly's theorem with volumes, Amer. Math. Monthly 91 (1984), no. 6, 362-365.

[BKP82] I. Bárány, M. Katchalski, and J. Pach, Quantitative Helly-type theorems, Proc. Amer. Math. Soc. 86 (1982), no. 1, 109-114.

[BGW82] U. Betke, P. Gritzmann, and J. M. Wills, Slices of L. Fejes Tóth's sausage conj, Mathematika 29 (1982), no. 2, 194-201 (1983).

[Bez13] K. Bezdek, Tarski's plank problem revisited, Geometry-intuitive, discrete, and convex, Bolyai Soc. Math. Stud., vol. 24, János Bolyai Math. Soc., Budapest, 2013, pp. 45-64.

[BM19] D. Bilyk and R. W. Matzke, On the Fejes Tóth problem about the sum of angles between lines, Proc. Amer. Math. Soc. 147 (2019), no. 1, 51-59, DOI $10.1090 / \mathrm{proc} / 14263$. MR3876730

[Bör83] K. Böröczky, The problem of Tammes for $n=11$, Studia Sci. Math. Hungar. 18 (1983), no. 2-4, 165-171.

[BFH13] K. J. Böröczky, F. Fodor, and D. Hug, Intrinsic volumes of random polytopes with vertices on the boundary of a convex body, Trans. Amer. Math. Soc. 365 (2013), no. 2, 785-809. 
[BS03] K. Böröczky and L. Szabó, Arrangements of 14, 15, 16 and 17 points on a sphere, Studia Sci. Math. Hungar. 40 (2003), no. 4, 407-421.

[BW03] K. Böröczky Jr. and G. Wintsche, Covering the sphere by equal spherical balls, Discrete and computational geometry, Algorithms Combin., vol. 25, Springer, Berlin, 2003, pp. 235-251.

[BGVV14] S. Brazitikos, A. Giannopoulos, P. Valettas, and B.-H. Vritsiou, Geometry of isotropic convex bodies, Mathematical Surveys and Monographs, vol. 196, American Mathematical Society, Providence, RI, 2014.

[Bru64] A. M. Bruckner, Some relationships between locally superadditive functions and convex functions, Proc. Amer. Math. Soc. 15 (1964), 61-65.

[Dan86] L. Danzer, Finite point-sets on $S^{2}$ with minimum distance as large as possible, Discrete Math. 60 (1986), 3-66.

[DR50] A. Dvoretzky and C. A. Rogers, Absolute and unconditional convergence in normed linear spaces, Proc. Nat. Acad. Sci. U. S. A. 36 (1950), 192-197.

[ER61] P. Erdős and C. A. Rogers, Covering space with convex bodies, Acta Arith. 7 (1961/1962), 281-285.

[Fár49] I. Fáry, Sur la courbure totale d'une courbe gauche faisant un nœud, Bull. Soc. Math. France 77 (1949), 128-138 (French).

[FTK93] G. Fejes Tóth and W. Kuperberg, Packing and covering with convex sets, Handbook of convex geometry, Vol. A, B, North-Holland, Amsterdam, 1993, pp. 799-860.

[FT72] L. Fejes Tóth, Lagerungen in der Ebene auf der Kugel und im Raum, SpringerVerlag, Berlin-New York, 1972.

[FT56] L. Fejes Tóth, On the sum of distances determined by a pointset., Acta Math. Acad. Sci. Hungar. 7 (1956), 397-401.

[FT73] L. Fejes Tóth, Research Problems: Exploring a Planet, Amer. Math. Monthly 80 (1973), no. 9, 1043-1044.

[FT43] L. Fejes Tóth, Über eine Abschätzung des kürzesten Abstandes zweier Punkte eines auf einer Kugelfläche liegenden Punktsystems, Jber. Deutsch. Math. Verein. 53 (1943), 66-68 (German).

[FT59] L. Fejes Tóth, Über eine Punktverteilung auf der Kugel, Acta Math. Acad. Sci. Hungar 10 (1959), 13-19 (German). 
[FNN16] N. Frankl, J. Nagy, and M. Naszódi, Coverings: variations on a result of Rogers and on the Epsilon-net theorem of Haussler and Welzl, arXiv:1607.02888 (2016).

[Fro53] O. Frostman, A theorem of Fáry with elementary applicatons, Nordisk Mat. Tidskr. 1 (1953), 25-32, 64.

[FK08] Z. Füredi and J.-H. Kang, Covering the $n$-space by convex bodies and its chromatic number, Discrete Math. 308 (2008), no. 19, 4495-4500.

[GG45] A. W. Goodman and R. E. Goodman, A circle covering theorem, Amer. Math. Monthly 52 (1945), 494-498, DOI 10.2307/2304537. MR0013513

[Gru07] P. M. Gruber, Convex and discrete geometry, Grundlehren der Mathematischen Wissenschaften [Fundamental Principles of Mathematical Sciences], vol. 336, Springer, Berlin, 2007.

[GS05] P. M. Gruber and F. E. Schuster, An arithmetic proof of John's ellipsoid theorem, Arch. Math. (Basel) 85 (2005), no. 1, 82-88.

[Hár86] L. Hárs, The Tammes problem for $n=10$, Studia Sci. Math. Hungar. 21 (1986), no. 3-4, 439-451.

[Hil66] E. Hille, Some geometric extremal problems, J. Austral. Math. Soc. 6 (1966), $122-128$.

[Pet14] F. Petrov, http://mathoverflow. net/questions/173712/ maximum-sum-of-angles-between-n-lines, 2014. Last accessed: July $30,2015$.

[Jia08] M. Jiang, On the sum of distances along a circle, Discrete Math. 308 (2008), no. 10, 2038-2045.

[JP17] Z. Jiang and A. Polyanskii, Proof of László Fejes Tóth's zone conj, Geom. Funct. Anal. 27 (2017), no. 6, 1367-1377, DOI 10.1007/s00039-017-0427-6. MR3737365

[Joh48] F. John, Extremum problems with inequalities as subsidiary conditions, Studies and Essays Presented to R. Courant on his 60th Birthday, January 8, 1948, Interscience Publishers, Inc., New York, N. Y., 1948, pp. 187-204.

[Lar62] H. Larcher, Solution of a gemetric problem by Fejes Tòth, Michigan Math. J. 9 (1962), 45-51. 
[Lin74] J. Linhart, Eine extremale Verteilung von Grosskreisen, Elem. Math. 29 (1974), 57-59 (German).

[LYZ04] E. Lutwak, D. Yang, and G. Zhang, Volume inequalities for subspaces of $L_{p}$, J. Differential Geom. 68 (2004), no. 1, 159-184.

[KN16] L. Kérchy and G. P. Nagy, A 2015. évi Schweitzer Miklós Matematikai Emlékverseny, www.bolyai.hu/schweitzer_beszamolo_2015.pdf (last accessed: March 10, 2017) (2016).

$[\mathrm{MP}]$ V. D. Milman and A. Pajor, Isotropic position and inertia ellipsoids and zonoids of the unit ball of a normed n-dimensional space, Geometric Aspects of Functional Analysis: Israel Seminar (GAFA) 1987-88 (J. Lindenstrauss and V. D. Milman, eds.), Vol. 1376, Springer, 1989, pp. 64-104, DOI $10.1007 / \mathrm{BFb} 0090049$.

[MT15] O. R. Musin and A. S. Tarasov, The Tammes Problem for $N=14$, Exp. Math. 24 (2015), no. 4, 460-468.

[MT12] O. R. Musin and A. S. Tarasov, The strong thirteen spheres problem, Discrete Comput. Geom. 48 (2012), no. 1, 128-141.

[Nas16a] M. Naszódi, On some covering problems in geometry, Proc. Amer. Math. Soc. 144 (2016), no. 8, 3555-3562, DOI 10.1090/proc/12992. MR3503722

[Nas16b] M. Naszódi, Proof of a conjecture of Bárány, Katchalski and Pach, Discrete Comput. Geom. 55 (2016), no. 1, 243-248, DOI 10.1007/s00454-015-9753-3.

[Nie65] F. Nielsen, On the sum of the distances between $n$ points on a sphere., Nordisk Mat. Tidskr. 13 (1965), 45-50 (Danish).

[Peł90] A. Pełczyński, Remarks on John's theorem on the ellipsoid of maximal volume inscribed into a convex symmetric body in $\mathbf{R}^{n}$, Note Mat. 10 (1990), no. suppl. $2,395-410$.

[PS91] A. Pełczyński and S. J. Szarek, On parallelepipeds of minimal volume containing a convex symmetric body in $\mathbf{R}^{n}$, Math. Proc. Cambridge Philos. Soc. 109 (1991), no. 1, 125-148.

[Piv10] P. Pivovarov, On determinants and the volume of random polytopes in isotropic convex bodies, Geom. Dedicata 149 (2010), 45-58.

[Rob61] R. M. Robinson, Arrangements of 24 points on a sphere, Math. Ann. 144 (1961), 17-48. 
[Ros72] V. Rosta, An extremal distribution of three great circles, Mat. Lapok 23 (1972), 161-162 (1973) (Hungarian).

[Sch14] R. Schneider, Convex bodies: the Brunn-Minkowski theory, Second expanded edition, Encyclopedia of Mathematics and its Applications, vol. 151, Cambridge University Press, Cambridge, 2014.

[Sch] R. Schneider, Discrete aspects of stochastic geometry, Handbook of discrete and computational geometry (J. E. Goodman, J. O'Rourke, and C. D. Tóth, eds.), Discrete Mathematics and its Applications (Boca Raton), CRC Press, Boca Raton, FL, 2018. Third edition, pp. 299-329.

[SW08] R. Schneider and W. Weil, Stochastic and integral geometry, Probability and its Applications (New York), Springer-Verlag, Berlin, 2008.

[SvdW51] K. Schütte and B. L. van der Waerden, Auf welcher Kugel haben 5, 6, 7, 8 oder 9 Punkte mit Mindestabstand Eins Platz?, Math. Ann. 123 (1951), 96-124 (German).

[Spe60] G. Sperling, Lösung einer elementargeometrischen Frage von Fejes Tóth, Arch. Math. 11 (1960), 69-71 (German).

[Tam30] P. M. L. Tammes, On the origin of number and arrangement of the places of exit on pollen grains, Rec. Trv. Bot. Neerl 27 (1930), 1-84.

[Tar32] A. Tarski, Remarks on the degree of equivalence of polygons, Parametr. 2 (1932), 310-314.

[vdW52] B. L. van der Waerden, Punkte auf der Kugel. Drei Zusätze, Math. Ann. 125 (1952), 213-222 (German).

[Zag89] D. Zagier, The dilogarithm function in geometry and number theory, Number theory and related topics (Bombay, 1988), Tata Inst. Fund. Res. Stud. Math., vol. 12, Tata Inst. Fund. Res., Bombay, 1989, pp. 231-249. 